\title{
THE T CELL RECEPTOR/CD3 COMPLEX: A DYNAMIC PROTEIN ENSEMBLE
}

\author{
Hans Clevers, Balbino Alarcon, Thomas Wileman, and \\ Cox Terhorst
}

Laboratory of Molecular Immunology, Dana-Farber Cancer Institute, 44 Binney Street, Boston, Massachusetts 02115

\section{T CELL RECEPTORS DO NOT ACT ALONE}

A large body of information about antigen receptors on the surface of $\mathrm{T}$ lymphocytes has been gathered in the last five years $(1,2)$. T cell receptors use a variable region gene pool that is completely distinct from the variable genes of immunoglobulins. Indeed, $T$ cells recognize different antigenic entities than do B lymphocytes. The latter notion was most dramatically demonstrated by the many observations that led to the conclusion that $\mathrm{T}$ cell receptors corecognize processed nominal antigen and a gene product of the $M H C$ (3). Since T cell receptors (TCR) and MHC products are anchored in the plasma membrane of $\mathrm{T}$ lymphocytes and antigen-presenting cells, respectively, the TCR/antigen/MHC recognition takes place on the interface between the two cells. A localized and TCR-independent adhesion provides a stabilizing environment for the subtle ternary interaction, which is dependent upon the fine recognition of all three of its participants. From model studies with human cytotoxic T cells, it appears that this transient adhesion event is initiated prior to the interaction of TCR with antigen and MHC (4).

The $\mathrm{T}$ cell receptors for antigen and MHC consist of two disulfidelinked variable glycoproteins whose genes rearrange in $\mathrm{T}$ cells: the $\mathrm{T}$ cell receptor (TCR) $\alpha$ and $\beta$ chains $(1,2)$. The $\mathrm{T}$ cell receptor so defined subserves both antigen and $\mathrm{MHC}$ recognition. Cell fusion experiments (5) and transfection of TCR- $\alpha$ and $-\beta$ chain cDNAs of defined specificities between $T$ cell clones (6) confirm that the $\alpha / \beta$ heterodimer confers both 
antigen and self-MHC specificity upon the cell that expresses it. Recently, human and murine $\mathrm{T}$ cell clones have been described that express other receptor molecules, TCR $-\gamma / \delta(1,2,7,8)$ or TCR $-\gamma / \gamma(9)$ on their surfaces. Although some of those cells have natural killer (NK)-like activities, the function of TCR- $\gamma^{+} / \delta^{+}$lymphocytes has not been elucidated and their target antigens (TCR $-\gamma / \delta$ ligands) are unknown. None of the TCR $-\gamma / \delta$ or TCR $-\gamma / \gamma$ killer T cell clones acts in an MHC-restricted fashion; the current hypothesis therefore is that only TCR $-\alpha / \beta$ receptors corecognize MHC and antigen.

The molecular basis of the recognition of MHC and MHC/antigen is not yet established. A large body of experimental evidence now favors the notion that the final $\mathrm{T}$ cell repertoire is selected from a pool of randomly generated TCRs based on MHC recognition $(10,11)$. Hedrick and colleagues (12) recently examined TCR- $\alpha$ and $-\beta$ gene expression in a series of class II MHC alloreactive T cell clones and in antigen-specific clones restricted by the same class II MHC elements. They found that the same $\mathrm{V} \alpha$ and $\mathrm{V} \beta$ gene segments were used. Apparently, TCRs mediating allorecognition of Ia antigens are homologous or identical to TCRs involved in recognition of the same Ia antigens in association with nominal antigen. This suggests that MHC-restricted recognition and alloreaction are not distinct events but rather represent differences in the affinity of TCR/MHC interactions.

Since recognition of nominal antigen and MHC by TCR most likely takes place after an adhesion occurs between a $\mathrm{T}$ cell and an antigen presenting cell, several $\mathrm{T}$ cell surface glycoproteins formerly called "accessory molecules" have turned out to be adhesion structures. Primary adhesion molecules on the surface of $\mathrm{T}$ lymphocytes are the cell surface proteins CD2 and LFA-1 (13). Convincing experimental evidence supports the idea that $\mathrm{CD} 2$ molecules on the $\mathrm{T}$ cell bind with high affinity to LFA3 embedded in the plasma membrane of the juxtaposed antigen-presenting cell. A molecule termed I-CAM is probably one of the cell-bound ligands for the LFA-1 structure. CD8 and CD4 most likely interact with a nonpolymorphic region of the class I and class II MHC molecules, respectively $(1,14)$. Not only are the postulated interactions between CD4/CD8 and MHC structures worthy of in-depth molecular studies, so is the implied proximity of CD4 or CD8 and TCRs. The latter type of transient interactions may be of crucial importance for the triggering of $\mathrm{T}$ cell functions $(15,15 a)$.

Interactions of the adhesion molecules with their respective ligands not only stabilize cell/cell contact, they also send either positive or negative signals to the $\mathrm{T}$ cell proliferative pathway induced by TCR/antigen/MHC interactions. The appropriate antibodies directed at $\mathrm{CD} 2$ can induce $\mathrm{T}$ cell 


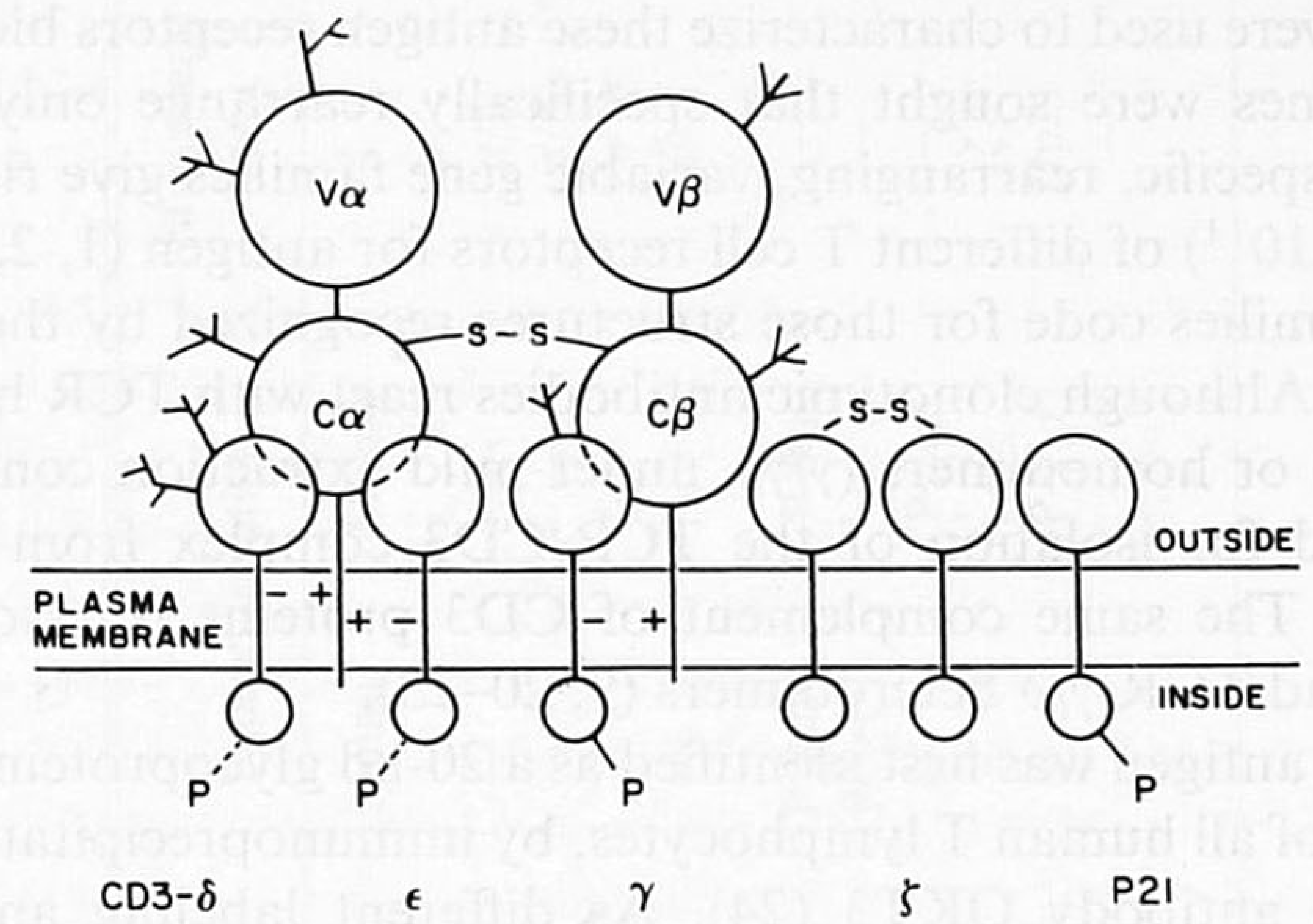

Figure 1 The TCR/CD3 complex indicates N-linked glycosylation. S-S indicates sulfhydryl bridges. $\mathrm{P}$ indicates sites of phosphorylation.

proliferation even in cells that do not express the TCR on their cell surface. By contrast, antibodies directed at CD4 and CD8 only cause T cell activation in combination with anti-TCR/CD3 reagent (15).

TCRs do not appear to act alone in the complex pathways of antigendriven $\mathrm{T}$ cell proliferation. Instead, they operate within a network of interactions that is only partially understood. TCRs are thought to transmit the signal provided by ligand/receptor interaction across the plasma membrane. To this end, the variable, or clonotypic, TCR $\alpha / \beta$ or $\gamma / \delta$ heterodimers may relay that signal through the invariant $\mathrm{CD} 3$ proteins $(\mathrm{CD} 3-\gamma, \delta, \varepsilon$, and $\zeta)$. Together, these polypeptide chains form the TCR/CD3 complex (Figure 1). Since this TCR/CD3 complex transiently associates with other proteins like CD3-p21 and perhaps with CD4 or $\mathrm{CD} 8$, the TCR/CD3 complex operates as a dynamic ensemble of proteins whose members differ depending on its functional state. Our current knowledge of its structure, assembly, and function are discussed in this review.

\section{CURRENT VIEWS ON THE STRUCTURE OF THE T CELL RECEPTOR/CD3 COMPLEX}

\section{The TCR/CD3 Complex on the Cell Surface}

Antigen receptors on the surface of human and mouse $\mathrm{T}$ lymphocytes have been discovered through two lines of experimental research. First, monoclonal antibodies (MAbs) specific for functionally competent in vitro cultured $\mathrm{T}$ cell clones were made $(16,17)$. These clone-specific or clonotypic antibodies were shown to affect the function of their respective $\mathrm{T}$ cell 
clone and were used to characterize these antigen receptors biochemically. Second, genes were sought that specifically rearrange only in $\mathrm{T}$ cells. The $\mathrm{T}$-cell-specific, rearranging, variable gene families give rise to a large number $\left(>10^{11}\right)$ of different $T$ cell receptors for antigen $(1,2,18,19)$ and the gene families code for those structures recognized by the clonotypic antibodies. Although clonotypic antibodies react with TCR heterodimers $(\alpha / \beta$ or $\gamma / \delta)$ or homodimers $(\gamma / \gamma)$, under mild extraction conditions they can be used for isolation of the TCR/CD3 complex from the plasma membrane. The same complement of $\mathrm{CD} 3$ proteins is associated with TCR- $\alpha / \beta$ and TCR- $\gamma / \delta$ heterodimers $(9,20-23)$.

The CD3 antigen was first identified as a $20-\mathrm{kd}$ glycoprotein, present on the surface of all human $T$ lymphocytes, by immunoprecipitation with the monoclonal antibody OKT3 (24). As different labeling and immunoprecipitation methods were used, the structure of the CD3 antigen appeared more complex. Thus, soon after, the CD3 antigen was found to be expressed as a complex composed of the major glycoprotein of $20 \mathrm{kd}$, a 25-28 kd glycoprotein, and two minor glycoproteins of 37 and $44 \mathrm{kd}$ $(25,26)$. The existence of a $20 \mathrm{kd}$ nonglycosylated protein was suspected, since upon treatment with endoglycosaminidases $\mathrm{H}$ and $\mathrm{F}$ (Endo $\mathrm{H}$ and F), a portion of the 20-kd proteins remained undigested (26-28). Definitive proof for a second 20 -kd protein was obtained when tryptic peptide maps and partial N-terminal sequences of both proteins were compared (29) and when monoclonal antibodies were raised that distinguished between the two 20 -kd CD3 proteins by immunoblotting (30). At this point the largest CD3 proteins, the 44-kd and 37-kd polypeptides, were identified as the TCR- $\alpha$ and $-\beta$ chains $(31,32)$. The $25-28 \mathrm{kd}$ glycoprotein was therefore termed CD3- $\gamma$; the $20-\mathrm{kd}$ glycoprotein, CD3- $\delta$; and the $20-\mathrm{kd}$ nonglycosylated protein CD3- $\varepsilon(28,29)$.

Several lines of evidence support the concept that the TCR- $\alpha / \beta$ heterodimer is associated with the CD3 proteins (Figure 1). First, coprecipitation of the CD3 proteins with anti-TCR reagents and vice versa indicated a close proximity of these cell surface structures. Second, incubation of T cells with MAbs directed against either TCR or CD3, or incubation of antigen-specific cloned $\mathrm{T}$ cells with antigenic peptides, leads to "co-modulation" or simultaneous disappearance from the cell surface of both structures $(33,34)$. Third, several mutants that do not express the TCR/CD3 complex on their surface have been analyzed and found to lack the TCR$\alpha$ or TCR- $\beta$ mRNA's. Upon gene transfer of either TCR- $\alpha$ or TCR- $\beta$, cDNA's cell surface expression of the TCR/CD3 complex could be restored to normal levels $(35,36)$.

More recent studies of the murine TCR/CD3 complex added new members to the CD3 family (Figure 1 and Table 1). Murine TCR-associated 
THE TCR/CD3 COMPLEX

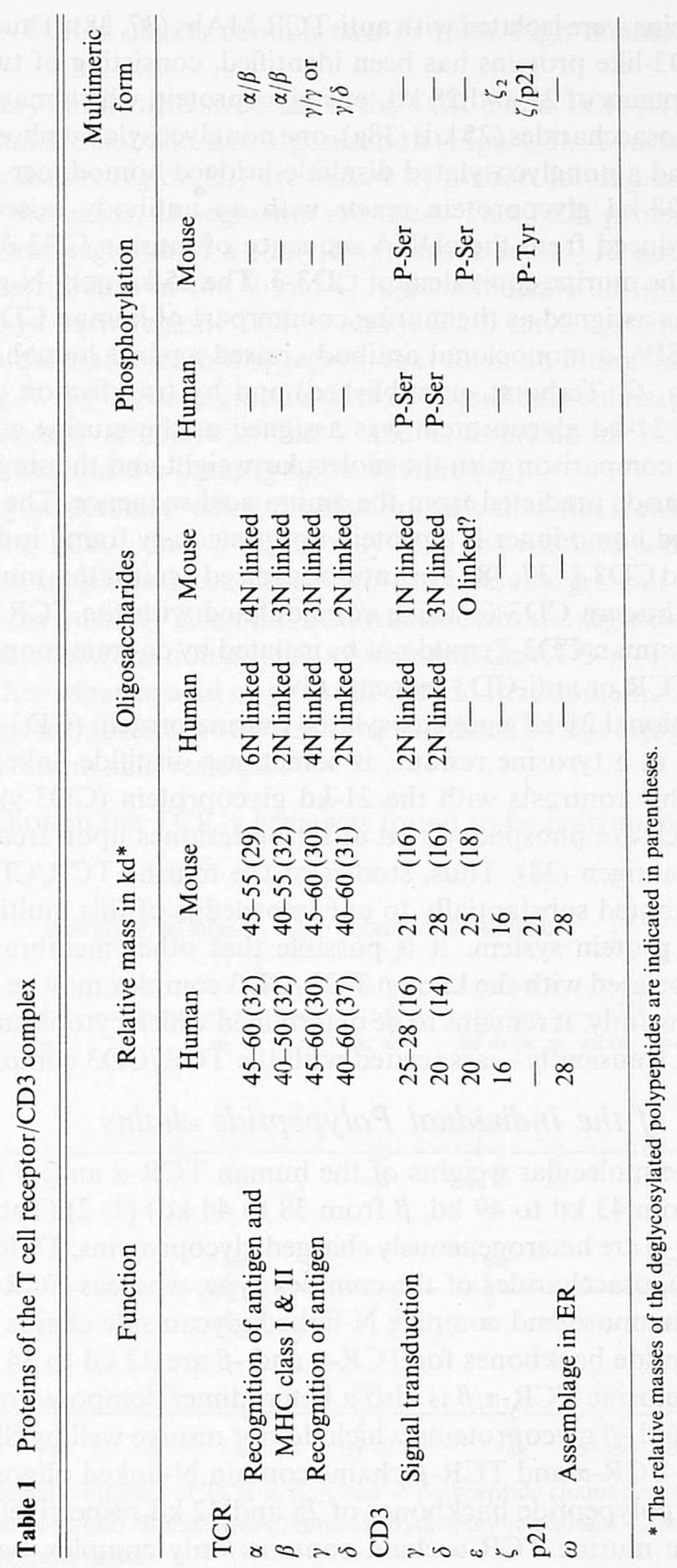


CD3 proteins were isolated with anti-TCR MAbs $(37,38)$. Thus, a complex of five CD3-like proteins has been identified, consisting of two N-glycosylated proteins of 21 and $28 \mathrm{kd}$, one glycoprotein which may contain Olinked oligosaccharides ( $25 \mathrm{kd}$ ) (38a), one nonglycosylated phosphoprotein $(21 \mathrm{kd})$, and a nonglycosylated disulfide-bridged homodimer (17 kd) (37, 38 ). The 28-kd glycoprotein reacts with an antibody raised against a peptide deduced from the cDNA sequence of murine CD3- $\delta$ (38) and is therefore the murine equivalent of CD3- $\delta$. The $25-\mathrm{kd}$ non- $\mathrm{N}$-glycosylated protein was assigned as the murine counterpart of human CD3- $\varepsilon$ by reaction with SP6, a monoclonal antibody raised against human CD3- $\varepsilon$ (30; B. Alarcon, C. Terhorst, unpublished) and by transfection experiments (38a). The 21-kd glycoprotein was assigned as the murine equivalent of CD3- $\gamma$, by comparison with the molecular weight and the single $\mathrm{N}$-linked oligosaccharide predicted from the amino acid sequence. The 34-kd nonglycosylated homodimer is a protein not previously found in human cells and is called CD $3-\zeta(37,38)$. An antibody raised against this murine protein detected a human $\mathrm{CD} 3-\zeta$, which comodulated with the TCR $\alpha / \beta$ chains. However, human CD3- $\zeta$ could not be isolated by co-immunoprecipitation with anti-TCR or anti-CD3 reagents (39).

An additional 21-kd nonglycosylated murine protein (CD3-p21), phosphorylated at a tyrosine residue, is sometimes disulfide-linked to CD3- $\zeta$ $(40,41)$. This contrasts with the $21-\mathrm{kd}$ glycoprotein $(\mathrm{CD} 3-\gamma)$ and $25-\mathrm{kd}$ CD3- $\varepsilon$ which are phosphorylated at serine residues upon treatment with PMA and antigen (38). Thus, studies of the murine TCR/CD3 complex have contributed substantially to our knowledge of this multicomponent membrane protein system. It is possible that other membrane proteins weakly associated with the known TCR/CD3 complex may be discovered. More importantly, it remains to be determined which cytoplasmic proteins are - albeit transiently - associated with the TCR/CD3 complex.

\section{Structure of the Individual Polypeptide chains}

TCR- $\alpha \beta \quad$ The molecular weights of the human TCR- $\alpha$ and $-\beta$ chains vary in size ( $\alpha$ from $43 \mathrm{kd}$ to $49 \mathrm{kd} ; \beta$ from 38 to $44 \mathrm{kd}$ ) $(1,2)$ (Table 1 ). Both TCR- $\alpha$ and $-\beta$ are heterogeneously charged glycoproteins; TCR- $\alpha$ contains $\mathrm{N}$-linked oligosaccharides of the complex type, whereas TCR- $\beta$ contains both high mannose and complex $\mathrm{N}$-linked glycan side chains $(1,27,28)$. The polypeptide backbones for TCR- $\alpha$ and $-\beta$ are $32 \mathrm{kd}$ to $34 \mathrm{kd}$, respectively. The murine TCR- $\alpha / \beta$ is also a heterodimer composed of 40 - to 50 kd TCR- $\alpha$ and $-\beta$ glycoproteins which do not resolve well by SDS-PAGE. The murine TCR- $\alpha$ and TCR- $\beta$ chains contain N-linked oligosaccharides attached to polypeptide backbones of 28 and $32 \mathrm{kd}$ respectively (1). As in humans, the murine TCR- $\alpha$ chain contains only complex type glycans, 
whereas the TCR- $\beta$ chains contain two or three high mannose glycans $(1,2)$.

The primary amino acid structure of the TCR- $\alpha$ and TCR- $\beta$ (2) proteins shows an immunoglobulin-like organization (Figure 2). A variable region (V) and a constant region (C) are linked by a short joining segment (J); in some of the genes, D segments are used. The TCR proteins have a transmembrane region and a short cytoplasmic tail (5-12 amino acids). Two cysteine residues in the $\mathrm{V}$ and $\mathrm{C}$ regions indicate an intrachain disulfide loop in each region. TCR- $\alpha$ and TCR- $\beta$ have cysteine residues, proximal to the transmembrane region, that form an interchain disulfide bond. Using X-ray crystallographic data of immunoglobulins, predictions for the secondary structure of the $\mathrm{V}$ and $\mathrm{C}$ domains of TCR- $\alpha$ and $\beta$ suggest that they have a basic Ig fold structure (42).

Secondary structure predictions also suggest that the transmembrane domain of the TCR- $\alpha$ and - $\beta$ chains may be in the $\alpha$-helical configuration. Assuming an amphipathic $\alpha$-helix, two positive charges can be accommodated in the putative 20 amino acid transmembrane segment. Since the TCR- $\beta$ transmembrane domain has a lysine and the CD $3-\gamma,-\delta$, and $-\varepsilon$ each contains either aspartic acid or glutamic acid in that domain, interactions between these membrane proteins may be stabilized by salt bridges between the charged amino acid residues.

TCR- $\gamma / \delta$ Although the TCR- $\gamma$ gene was found to be rearranged and tran-
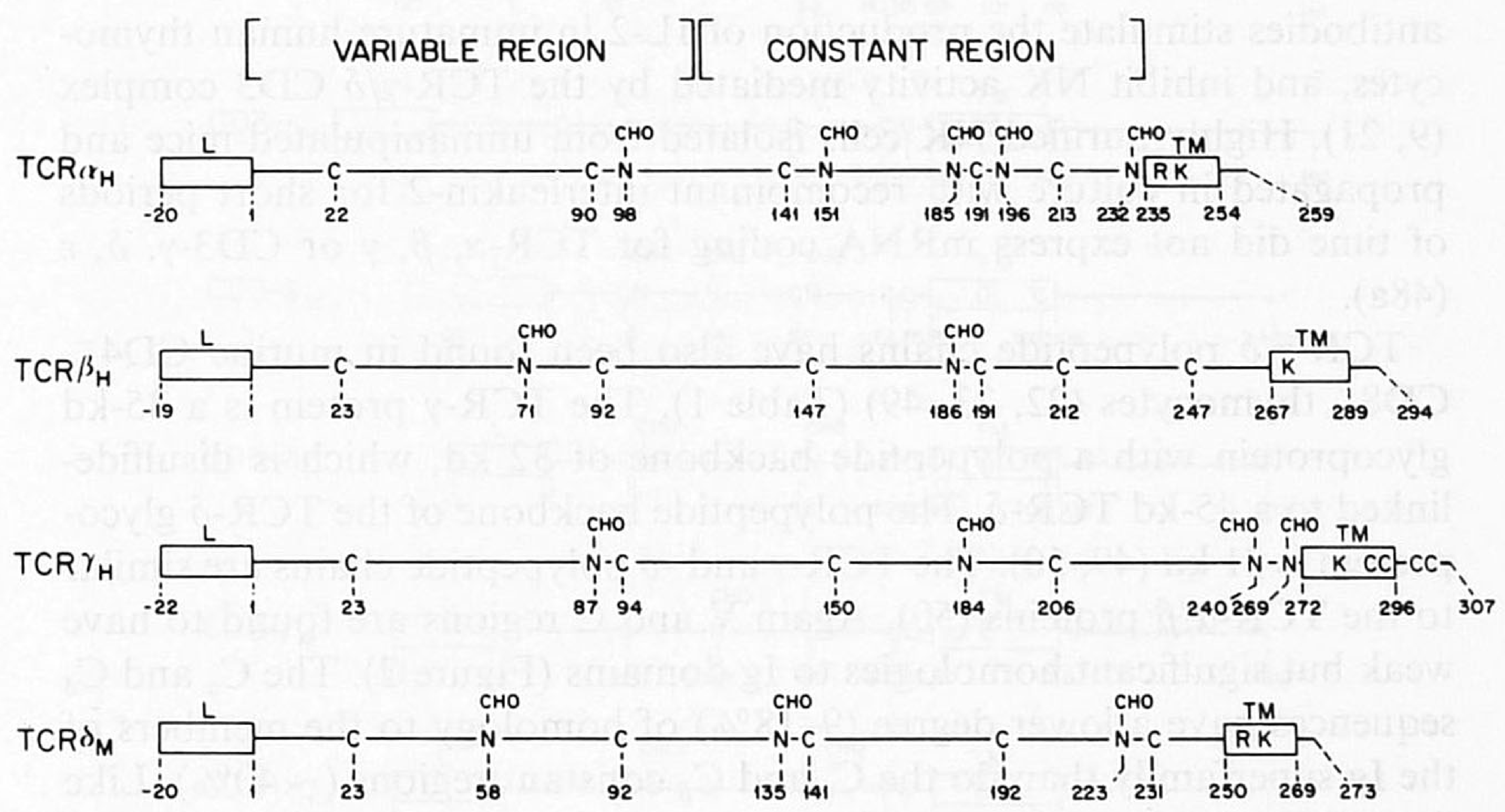

Figure 2 Schematic outlines of TCR- $\alpha, \beta, \gamma$, and $-\delta$ polypeptide chains derived from Kabat (90) and Chien et al (50). Boxed areas represent hydrophobic regions. L, leader sequence, $\mathrm{TM}$, transmembrane region. 
scribed in mouse $(43,44)$ and human $(45) \mathrm{T}$ lymphocytes, the nature of the TCR- $\gamma$ protein product has been a mystery for some time. A number of human $\mathrm{CD}^{-}, \mathrm{CD}^{-}, \mathrm{CD} 3^{+} \mathrm{T}$ cell clones with $\mathrm{NK}$ activity lack reactivity with WT31, a monoclonal antibody that recognizes a common epitope on human TCR- $\alpha / \beta$ chains $(7,8,9,46)$. A heterodimer composed of a $55-\mathrm{kd}$ and a $40-\mathrm{kd}$ protein was coprecipitated with anti-CD3 antibodies. Since the cells expressed neither TCR- $\alpha$ nor TCR- $\beta$ mRNA but did express TCR- $\gamma$ mRNA, the new CD3-associated proteins were candidates for a TCR $-\gamma$ gene product. By immunoprecipitation with an antipeptide anti-TCR- $\gamma$ antibody, the $55-\mathrm{kd}$ protein was demonstrated to be the TCR- $\gamma$ product, while the $40-\mathrm{kd}$ protein was a new TCR-like polypeptide termed TCR- $\delta(46)$. The $\mathrm{CD}^{+}, \mathrm{WT} 31^{-}, \mathrm{CD} 4^{-}, \mathrm{CD} 8^{-}, \mathrm{TCR}_{-}$ $\gamma / \delta^{+}$lymphocytes were demonstrated to constitute a small subpopulation of normal human peripheral lymphocytes $(0.5 \%-10 \%)$ and thymocytes $(0.2 \%-0.9 \%)(20)$.

In contrast with the TCR $-\alpha / \beta$ polypeptides, the TCR- $\gamma$ proteins are apparently expressed in several forms. The 55-kd TCR- $\gamma$ glycoprotein has a 29-kd polypeptide backbone and is the product of the $\mathrm{C} \gamma 2$ gene that lacks cysteine residues outside the transmembrane domain (47). Another human constant region gene, $\mathrm{C} \gamma 1$, encodes a protein that can form disulfide bridges. The products of this gene indeed form covalently linked TCR- $\gamma / \delta$ heterodimers. In addition to two types of TCR- $\gamma / \delta$ heterodimers, a $\gamma / \gamma$ disulfide-linked homodimer has been found in human $\mathrm{T}$ cell clones $(8,9$, 48). The TCR $-\gamma-\delta$ or TCR $-\gamma / \gamma$ structures are functional, since anti-CD3 antibodies stimulate the production of IL-2 in immature human thymocytes, and inhibit NK activity mediated by the TCR $-\gamma / \delta$ CD 3 complex $(9,21)$. Highly purified NK cells isolated from unmanipulated mice and propagated in culture with recombinant interleukin-2 for short periods of time did not express mRNA coding for TCR- $\alpha, \beta, \gamma$ or CD $3-\gamma, \delta, \varepsilon$ (48a).

TCR- $\gamma / \delta$ polypeptide chains have also been found in murine $\mathrm{CD}^{-}$, CD8 ${ }^{-}$thymocytes $(22,23,49)$ (Table 1$)$. The TCR- $\gamma$ protein is a $35-\mathrm{kd}$ glycoprotein with a polypeptide backbone of $32 \mathrm{kd}$, which is disulfidelinked to a $45-\mathrm{kd}$ TCR- $\delta$. The polypeptide backbone of the TCR- $\delta$ glycoprotein is $31 \mathrm{kd}(49,50)$. The TCR $-\gamma$ and $-\delta$ polypeptide chains are similar to the TCR $-\alpha / \beta$ proteins (50). Again $\mathrm{V}$ and $\mathrm{C}$ regions are found to have weak but significant homologies to Ig domains (Figure 2). The $\mathrm{C}_{\alpha}$ and $\mathrm{C}_{\delta}$ sequences have a lower degree (9-18\%) of homology to the members of the Ig superfamily than do the $\mathrm{C}_{\gamma}$ and $\mathrm{C}_{\beta}$ constant regions $(\sim 40 \%)$. Like that of $\mathrm{C}_{\alpha}$, the $\mathrm{C}_{\delta}$ transmembrane region probably forms an amphipathic helix with one or two positively charged residues. An estimate of the size of the TCR- $\gamma / \delta$ repertoire will have to await further sequence analyses. 
More importantly, the class of antigens recognized by TCR- $\gamma / \delta$ or TCR$\gamma / \gamma$ needs to be determined.

\section{The CD3 Polypeptide Chains}

The primary structures of the human and murine CD $3-\gamma,-\delta$, and $-\varepsilon$ chains have been derived from nucleotide sequences of the respective cDNAs (5156). An outline of the structure of these protein molecules is given in Figure 3. Each contains an $\mathrm{N}$-terminal extracellular domain, a transmembrane segment, and a cytoplasmic domain. In the case of the CD3- $\gamma$ and $-\delta$ glycoproteins, the presence of a consensus sequence for $\mathrm{N}$-linked glycosylation in the amino-terminal segment indicates that this segment is located extracellularly (Figure 3 ). The vectorial organization of CD3- $\varepsilon$ in the plasma membrane is derived from experiments with antipeptide reagents directed at the $\mathrm{N}$-terminus of the mature protein. In the case of both the human and the murine $\mathrm{CD} 3-\varepsilon$, these anti-N-terminal peptide sera stain $\mathrm{T}$ lymphocytes in an indirect immunofluorescence assay. In the case of the human CD3- $\varepsilon$, the antibody is mitogenic for peripheral blood $\mathrm{T}$ lymphocytes. (H. Clevers, C. Terhorst, unpublished.)

The transmembrane region of all known $\mathrm{CD} 3$ proteins contains a negatively charged amino acid which may be one of the components that

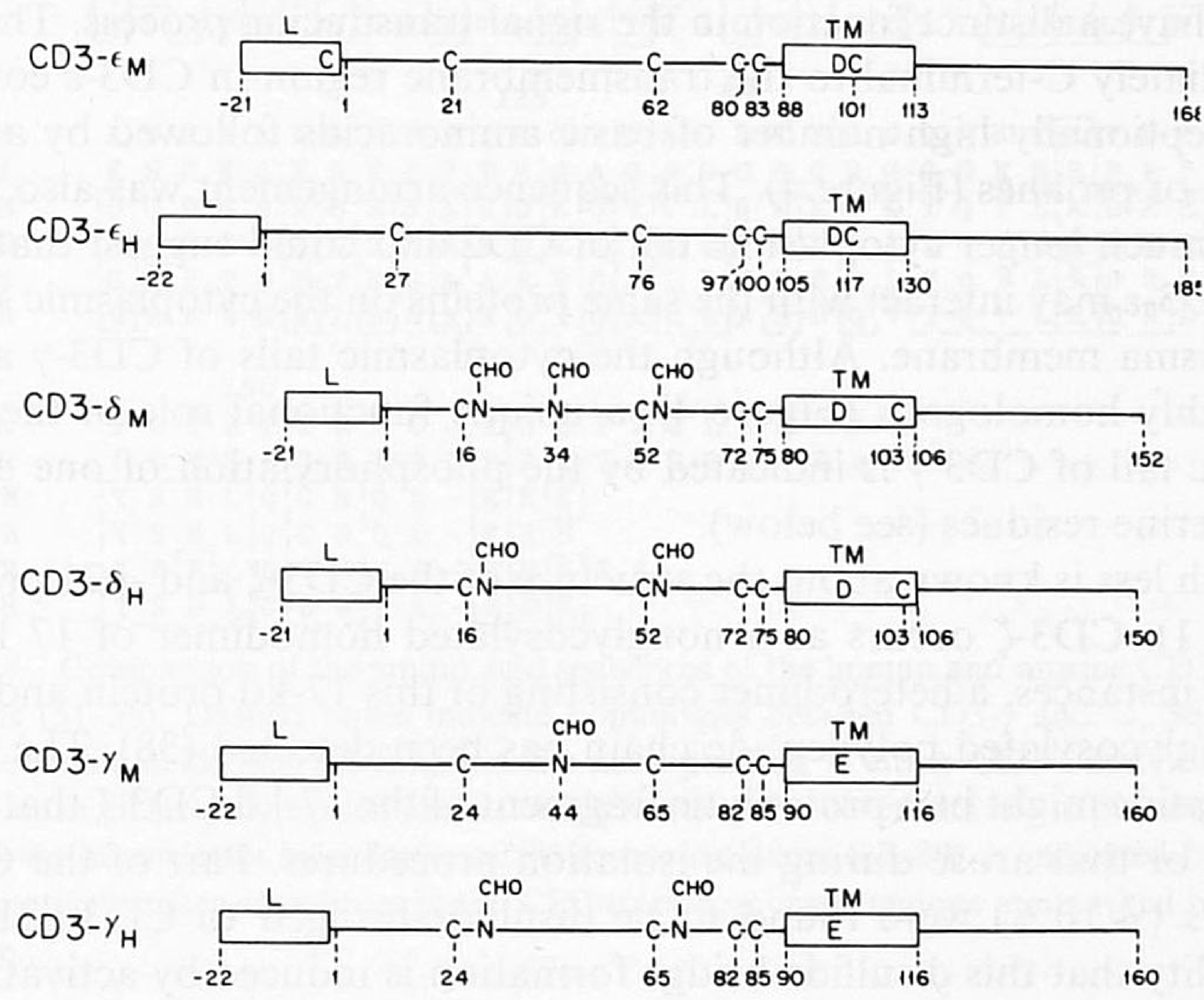

Figure 3 Schematic outline of the protein sequences of human and mouse CD3 proteins. (Legends, see Figure 2.) 
stabilize intersubunit interactions in the TCR/CD3 Complex (Figure 4). The proposed transmembrane segments of most of the CD-3 proteins have a predicted $\alpha$-helix configuration and form therefore amphipathic helixes. In human and murine CD3- $\delta$ and CD3- $\varepsilon$ chains, the transmembrane domain contains half cystine residues. Although fatty acid residues have often been found in covalent linkage to Cys residues in transmembrane segments of cell surface proteins, this posttranslational modification has never been observed in the case of the CD3- $\delta$ or CD3- $\varepsilon$ proteins, but the possibility that a fatty acid chain is attached to the murine CD3- $\varepsilon$ polypeptide cannot be excluded. Interestingly, a cDNA which does not contain a transmembrane region caused by an alternative splicing event has been isolated from a variant of the JURKAT cell line (56a). Whether this form of CD3- $\delta$ is secreted or whether it assembles into the TCR/CD3 complex remains to be determined. Since the cytoplasmic regions of the CD3 polypeptide chains are considerably longer than those of the TCR$\alpha,-\beta,-\gamma$, and $-\delta$ chains, these portions of the molecules presumably play an important role in the interaction with cytoplasmic components that are directly involved in the transduction of the antigen-binding signal: The available amino acid sequences do not reveal any homologies with phosphokinases or other enzymes known to be involved in transmembrane signal amplification pathways. Since the CD3- $\varepsilon$ cytoplasmic tail is completely different from its CD3- $\gamma$ and CD3 $\delta$ counterparts (Figure 4), CD3$\varepsilon$ may have a distinct function in the signal transducing process. The area immediately $\mathrm{C}$-terminal to the transmembrane region in CD $3-\varepsilon$ contains an exceptionally high number of basic amino acids followed by a short stretch of prolines (Figure 4). This sequence arrangement was also found in the much longer cytoplasmic tail of CD2 and could suggest that CD2 and CD3- $\varepsilon$ may interact with the same proteins on the cytoplasmic side of the plasma membrane. Although the cytoplasmic tails of CD3- $\gamma$ and $-\delta$ are highly homologous (Figure 4), a unique functional role of the cytoplasmic tail of CD3- $\gamma$ is indicated by the phosphorylation of one or two of its serine residues (see below).

Much less is known about the structure of the CD3- $\zeta$ and -p21 proteins (Table 1). CD3- $\zeta$ occurs as a nonglycosylated homodimer of $17 \mathrm{kd}$. In several instances, a heterodimer consisting of this $17-\mathrm{kd}$ protein and a $15-$ $\mathrm{kd}$ nonglycosylated polypeptide chain has been detected (38). The 15-kd polypeptide might be a proteolytic fragment of the $17-\mathrm{kd} \mathrm{CD} 3-\zeta$ that exists in vivo or that arose during the isolation procedures. Part of the CD3- $\zeta$ proteins $(\sim 10 \%)$ were found to be disulfide-bridged to CD3-p21. The possibility that this disulfide-bridge formation is induced by activation of the TCR/CD3 complex and links the receptor to the proliferative pathway needs to be investigated. Isolation of cDNA clones encoding CD3- $\zeta$ and 


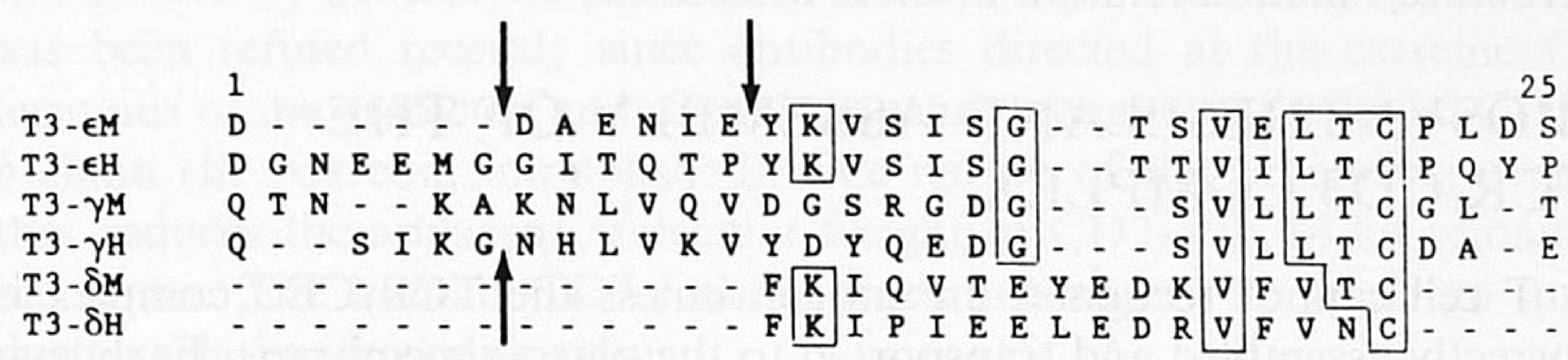

T3- $E$ M D - - - - D A E N I E Y $\mathrm{K}$ V S I S G - - T S V E L T T C P L D S

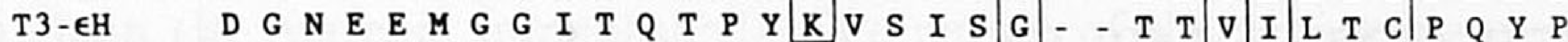
T3- - M Q T N - - K A K N L V Q V D G S R G D G - - S S V L L L T C G L - T

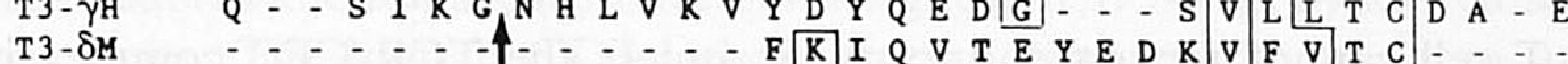
$\mathrm{T} 3-\delta \mathrm{H}$

D E N L K W E K N G Q E L P - Q K H D K - . - - H L V L Q D G S E E I L W Q

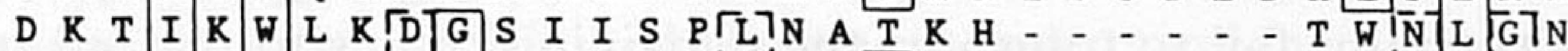

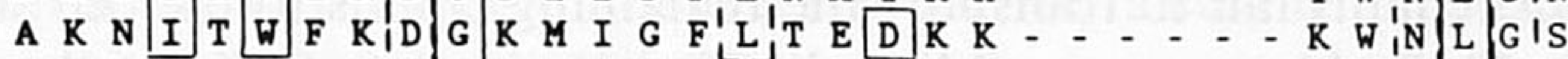

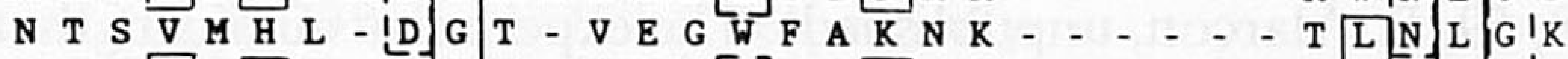
N T S I T W V - E G T - V G TLL]L S DI T - . . - R L D L G J K

T3- EM $\mathrm{T} 3-\epsilon \mathrm{H}$ T3 - $\gamma \mathrm{M}$ T3 $-\gamma \mathrm{H}$ T3- $\mathrm{MM}$ T3- $\mathrm{H}$

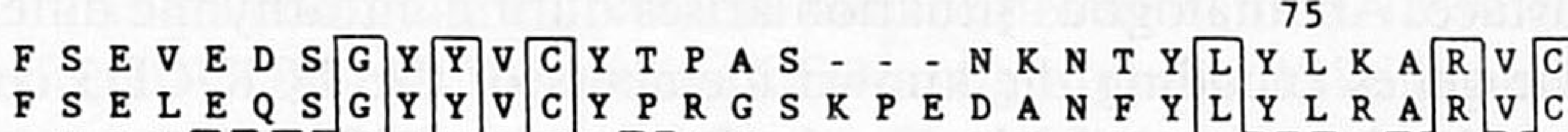
- N A KTD P R G T T Q C Q Q T GTA K - - - E T S N P L T - N A $\quad$ K

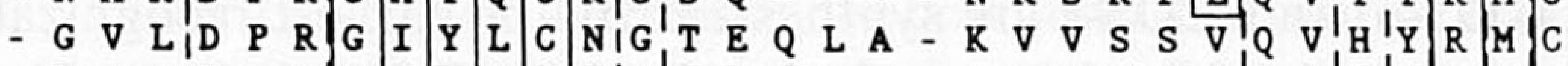
- R I L L_P_R G I I

T3-EM T3 $-\in H$ T3- $\gamma \mathrm{M}$ T3 $-\gamma \mathrm{H}$ T3- $\delta \mathrm{M}$ Т3 $-\delta \mathrm{H}$

T3-EM

T3 $-\epsilon \mathrm{H}$

T3 - $\gamma \mathrm{M}$

T3 $-\gamma \mathrm{H}$

T3-8M

T $3-\delta \mathrm{H}$

E Y C V E V D L T A V A I I I I V D I I C I T T L G L L L M V I Y Y Y W S

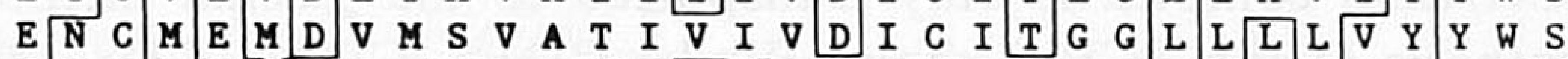

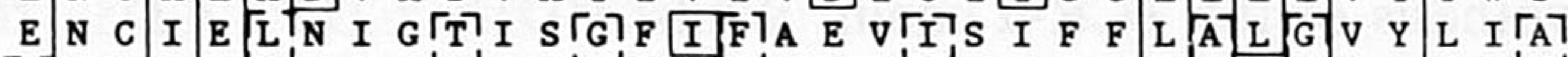
TQ 2 N Q Q N N C

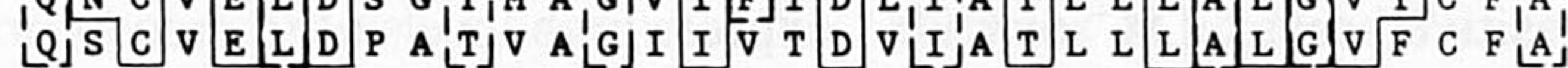

125

$\begin{array}{lllllllllllllllllllllllllllllllll}K & N & R & K & A & K & A & K & P & V & T & R & G & T & G & A & G & S & R & P & R & G & Q & N & K & E & R & P & P & P & V & P & N\end{array}$

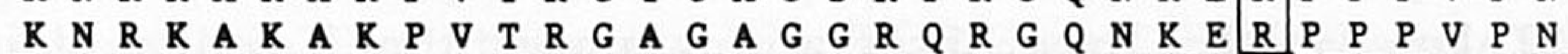

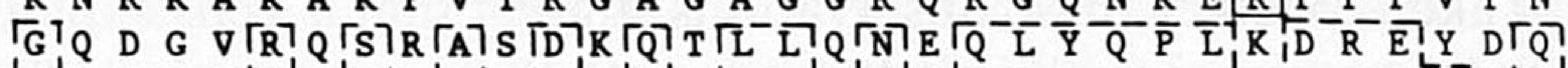

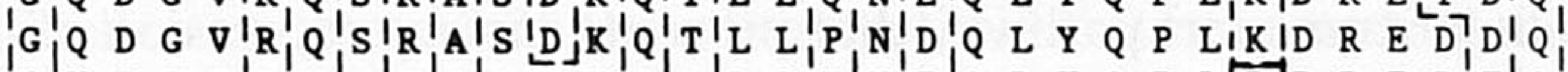

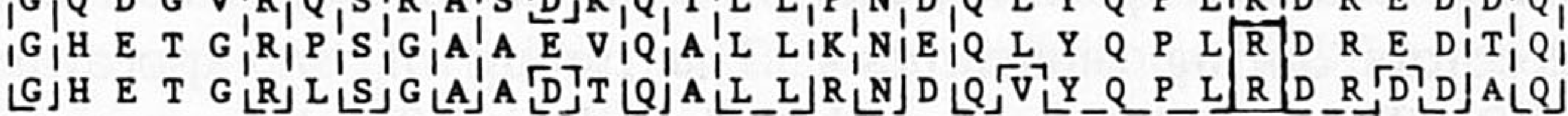

150

T3-EM P D Y E P I R K G Q R

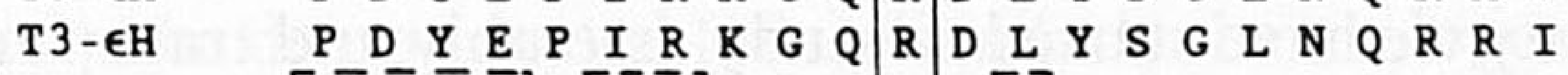

T $3-\gamma \mathrm{M}$

$\mathrm{T} 3-\gamma \mathrm{H}$

T3 $-\delta M$

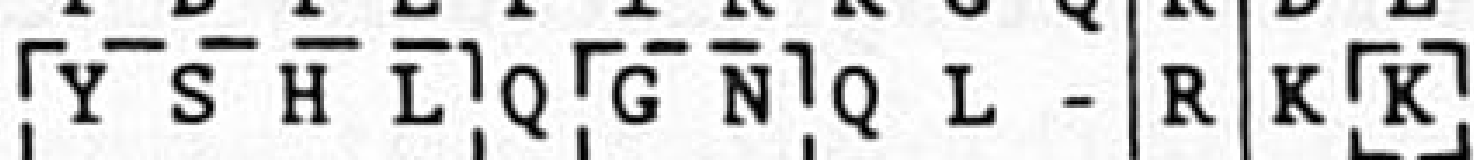

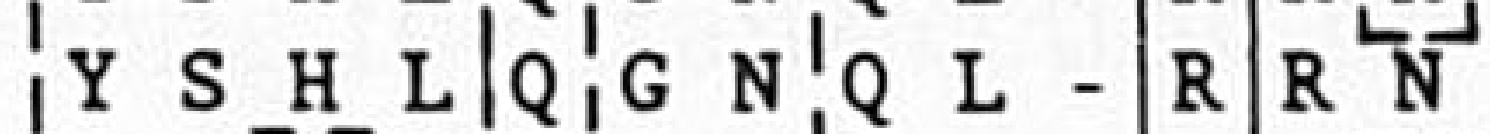

$\mathrm{T} 3-\delta \mathrm{H}$

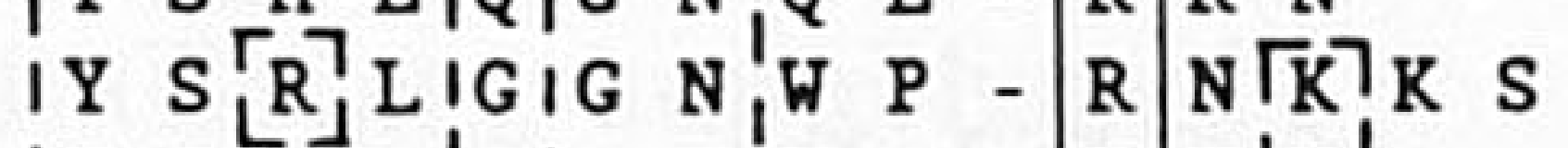
IY S_H_L'GIG_NJW A - R N'KJ'

Figure 4 Comparison of the amino acid sequences of the human and murine CD $3-\gamma, \delta$ and $\varepsilon$ chains (51-56). Dashed boxes indicate homologies between CD $3-\gamma$ and $-\delta$. Solid boxes indicate amino acids that are found in the same position in either CD3- $\varepsilon$ and in CD3- $\gamma$ or CD3- $\delta$ or in all six polypeptide chains. Alignments at the N-termini are in part based upon the known intron/exon boundaries of the respective genes (87-89) as indicated by arrows. The negatively charged residues in the CD 3 transmembrane regions are marked by a black triangle. 
CD3-p21 is of crucial importance to further our knowledge about the structure/function relation of these molecules.

\section{BIOSYNTHESIS AND ASSEMBLY OF THE TCR/CD3 COMPLEX}

A $T$ cell cannot recognize an antigen unless the TCR/CD3 complex is correctly assembled and transported to the plasma membrane. Early evidence that the processes of assembly and transport are complex comes from the demonstration that $\mathrm{T}$ cell mutants lacking one of the TCR or CD3 chains fail to transport the remaining chains to the cell surface (57, 58,59 ; B. Alarcon, unpublished). The experiments indicate that the $\mathrm{T}$ cell has a mechanism to prevent incomplete receptors from arriving at the cell surface. An analogous situation arises during intrathymic differentiation. The genes encoding the known members of the TCR/CD3 complex are expressed sequentially during the final stages of $\mathrm{T}$ cell maturation. CD3$\gamma, \mathrm{CD} 3-\delta$, and CD3- $\varepsilon$ are synthesized by the earliest recognizable thymocytes, but the proteins remain inside the cell (see below). Upon further maturation, $\mathrm{T}$ cells begin to express TCR- $\beta$ chains intracellularly. The TCR/CD3 complex is only transported to the plasma membrane after synthesis of the TCR- $\alpha$ chain. Whilst $\mathrm{CD}^{+}, \mathrm{CD} 4^{+}, \mathrm{CD} 8^{+}$thymocytes express low levels of the TCR/CD3 complex on their cell surface, "single positive" cells $\mathrm{CD}_{4}{ }^{+}$or $\mathrm{CD} 8{ }^{+}$express high levels of the receptor complex. The environment of the thymus gland may therefore influence the assembly process.

Taken together these observations suggest that $\mathrm{T}$ cells exploit an intracellular transport pathway that prevents surface expression of incomplete receptors during biosynthesis. The timing of the appearance of the TCR/CD3 complex at the cell surface during $T$ cell maturation can thus be controlled by the expression of a single chain of the complex. To understand this pathway we have started to study assembly and transport of the receptor in detail.

\section{Posttranslational Modification of CD3 Proteins}

The protein backbones of the human CD3- $\gamma$ and $-\delta$ chains have been calculated from their predicted amino acid sequences to be $16 \mathrm{kd}$. Both chains receive two $\mathrm{N}$-linked high-mannose oligosaccharides (Table 1). The glycosylated human $\mathrm{CD} 3-\delta$ chain migrates as a $20-\mathrm{kd}$ molecule. In contrast, the human CD3- $\gamma$ chain appears as a $23-\mathrm{kd}$ band early during biosynthesis, which in chase-labeling experiments matures to a protein of 25-28 kd (38a, 58). Removal of the two N-linked glycans from human CD3 $-\delta$ yields a protein backbone of $14 \mathrm{kd}$. This is at variance with its 
predicted molecular weight of $16 \mathrm{kd}$. It was proposed that this discrepancy was caused by proteolytic processing of the $\mathrm{C}$-terminus. This hypothesis has been refuted recently since antibodies directed at the extreme Cterminus of the predicted amino acid sequence recognized the 14-kd CD3$\delta$ chain (B. Alarcon, unpublished). The nature of the processing event that reduces the apparent molecular weight of CD3- $\delta$ to $14 \mathrm{kd}$ remains unknown. The human CD3- $\varepsilon$ chain does not appear to undergo any posttranslational modification.

The protein backbones of murine CD3- $\gamma,-\delta$, and $-\varepsilon$ are $16 \mathrm{kd}, 16 \mathrm{kd}$, and $17 \mathrm{kd}$, respectively. Again, the CD $3-\gamma$ and $-\delta$ chains are glycoproteins and addition of one or three $\mathrm{N}$-linked oligosaccharide raises their apparent molecular weights to $20 \mathrm{kd}$ and $25 \mathrm{kd}$, respectively.

These molecular weights have been confirmed by transfecting COS-cells with the cDNAs encoding the human and murine proteins (38a). In T cells and in transfected COS cells, the murine CD3- $\varepsilon$ migrates as a $25 \mathrm{kd}$ protein. However, the predicted molecular weight, confirmed by in vitro translation experiments, is only $18 \mathrm{kd}(54)$. Therefore, we conclude that murine CD3$\varepsilon$ undergoes an as-yet-unidentified posttranslational modification.

\section{The CD3- $\gamma,-\delta$, and $-\varepsilon$ Chains Form a CD3 "Subcomplex" (Figure 5)}

Several experiments show that a CD3 $-\gamma,-\delta,-\varepsilon$ core can form in the absence of TCR- $\alpha$ and/or TCR- $\beta$ chains. The earliest complex of proteins that can be observed during pulse-chase labeling experiments is one composed of CD $3-\gamma,-\delta$, and $-\varepsilon$. The independent assembly of the CD3 chains has also been demonstrated in T cell lines that lack TCR- $\alpha$ or TCR- $\beta$ chains (58), and in COS cells transfected with the relevant cDNAs. It is interesting that CD 3 chains are not transported to the plasma membrane of COS cells. By virtue of the high sequence homologies between human and mouse CD3 proteins, heterologous associations between these chains in COS cells could be demonstrated (38a). Similarly, heterologous CD3 complexes can form following the transfection of human CD3- $\varepsilon$ into a murine T-T hybridoma (H. Clevers, unpublished).

It is likely that the CD3 proteins form a core to which the TCR chains bind. It now seems clear from studies using $\mathrm{T}$ cell mutants and variants, that TCR- $\alpha$ and TCR- $\beta$ are independently associated with CD3. In human TCR- $\alpha^{-}$lines and TCR- $\alpha^{-}$mutants, a subcomplex of CD3- $\gamma \delta \varepsilon$ with TCR$\beta$ can be detected. Similarly, CD3- $\gamma \delta \varepsilon-$ TCR- $\alpha$ was found in a TCR- $\beta^{-}$ mutant (58). The binding of TCR- $\alpha$ and TCR- $\beta$ to CD3 might be a prerequisite for disulfide-bridged heterodimer formation. The $\mathrm{T}$ cell clone HY-827-P19 does not synthesize CD3 mRNAs but does produce considerable amounts of TCR- $\alpha$ and $-\beta$ chains. No TCR heterodimers are 


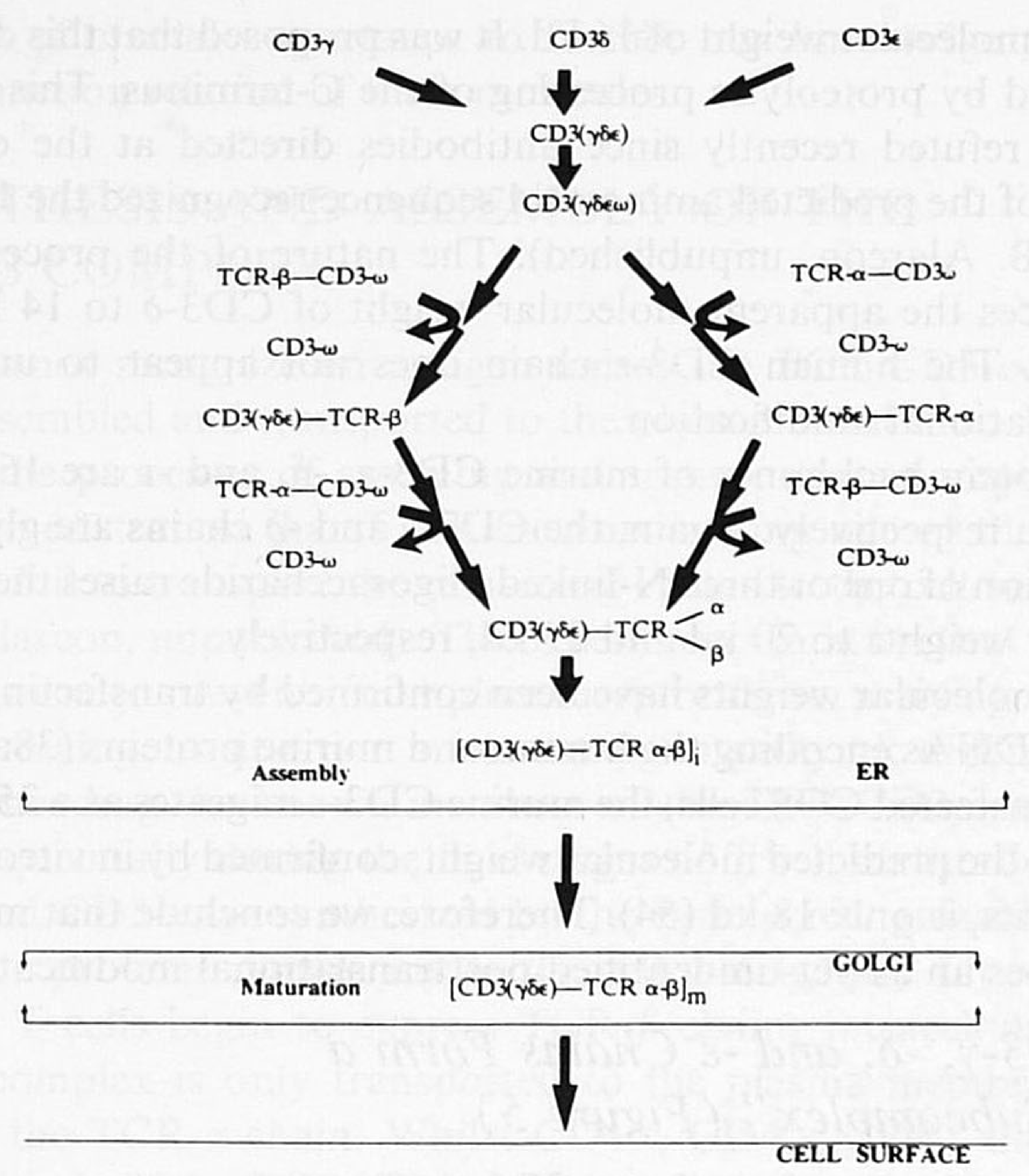

Figure 5 The assembly pathway of the TCR/CD3 complex (see text).

formed, even though they are found in the parent cell line HY-827 (B. Alarcon, unpublished).

Based on the types of analyses described here, we favor a model of hierarchy of assembly in which the CD3- $\gamma, \delta, \varepsilon$ chains form a core structure to which TCR $-\alpha / \beta$ chains bind. At this point, an alternative model in which the TCR $-\alpha / \beta$ and CD3- $\gamma, \delta, \varepsilon$ chains randomly associate in the mature T lymphocyte cannot be ruled out.

\section{The TCR- $\alpha / \beta-C D 3-\gamma, \delta, \varepsilon$ Complex Is Formed Within the} Endoplasmic Reticulum (Figure 5)

Regardless of the hierarchy of assembly described above, pulse-chase labeling experiments have shown that the CD3- $\gamma, \delta, \varepsilon$ proteins form a complex with the TCR- $\alpha / \beta$ heterodimer while residing in the endoplasmic reticulum. The evidence for this centers on the observation that complete assembly takes place before the N-linked oligosaccharides of the component chains have been modified by enzymes known to reside in the Golgi apparatus. Moreover, the addition of monensin, an inhibitor of Golgi functions, prevented the maturation of the oligosaccharides attached to 
the various polypeptide chains, but did not affect the TCR-CD3 assembly (58). Although the assembly of the TCR and CD3 chains is a rapid process, the export of the complex from the ER to the Golgi is slow, requiring $3 \mathrm{hr}$ for the processing of half the complexes from the Endo-H-sensitive to the Endo-H-resistant forms (58). This confirms earlier results of Borst et al (26), who showed that complete sialylation of the CD3 complex, a modification that occurs in the trans-elements of the Golgi, is also a slow process.

The factors that control the export of the complex from the ER to the Golgi stacks are unknown. The loosely associated CD3- $\zeta$ may play a crucial role (59). However, it is apparent that association of TCR/CD3 is not rate-limiting in driving export, since the assembly of CD3- $\zeta$ with the rest of the complex is very rapid (B. Alarcon, unpublished).

Recently, a new type of immune deficiency has been described that is characterized by the lack of TCR/CD3 expression on the surface of peripheral $\mathrm{T}$ lymphocytes, which were $\mathrm{CD} 2^{+}$and expressed normal levels of CD4 or CD8 (60). The TCR/CD3 complex was assembled in the endoplasmic reticulum as in normal $\mathrm{T}$ cells, but the complex was not exported to the Golgi apparatus (B. Alarcon, B. Regueiro, A. Arnaiz, and C. Terhorst, submitted). Although the reasons for this export defect are unknown, naturally occurring variants such as these may be helpful in elucidating the export mechanisms.

\section{Incompletely Assembled Receptor Complexes Do Not Reach the Plasma Membrane}

Many $\mathrm{T}$ cell mutants and $\mathrm{T}$ cell variants that lack one or more chains of the TCR/CD3 complex have been described. In the cases analyzed to date, the proteins that are synthesized assemble into "subcomplexes," but they remain inside the cell. Transport of the complex to the plasma membrane can be reconstituted by transfer of the cDNA encoding the missing chain into the mutants. Similarly, in COS cells, transfected CD $3-\gamma,-\delta$, and $-\varepsilon$ assemble but remain inside the cell. These observations are consistent with the notion that complete assembly of the TCR/CD3 complex is a prerequisite for export from the endoplasmic reticulum.

Not all the newly synthesized polypeptide chains appear to become incorporated into the receptor $(58,60 \mathrm{a})$. A major question posed by these results is the site of degradation. As degradation of polypeptide chains does not occur in the endoplasmic reticulum and since the TCR/CD3 complex is formed in the endoplasmic reticulum, a transport pathway from this organelle to a lysosomal (sub-)compartment has to exist. Studies using $\mathrm{T}$ cell mutants and variants and COS cell transfections show that the $\mathrm{N}$-linked glycans of the chains of partial complexes remain unprocessed. It 
seems likely, therefore, that they move directly from the endoplasmic reticulum to the degradative compartment via a pathway that avoids the distal stacks of the Golgi.

Site-directed mutagenesis experiments that introduce charged amino acids into the transmembrane domains of viral surface glycoproteins have resulted in retention of the protein inside the cell and interestingly, rapid degradation of the mutant protein within lysosomes $(61,62)$. It is possible that the charges within the transmembrane domains of the TCR/CD3 proteins (Figures 2 and 3 ) are responsible for their retention in the cell prior to assembly and may even direct unassembled chains and "subcomplexes" along a degradative pathway. During assembly, the negative charges of the CD3 proteins may be neutralized by the positive charges of the TCR. Regardless of mechanism, a series of mutagenesis experiments directed at the transmembrane regions of the TCR/CD3 proteins will define their particular role in assembly and transport. Other retention signals may, however, exist in the polypeptide chains that compose the TCR/CD3 complex.

\section{CD3- $\omega$ Plays a Role in Assembly (Figure 4)}

Pulse-chase biosynthetic labeling experiments detect a nonglycosylated polypeptide chain of $28 \mathrm{kd}(\mathrm{CD} 3-\omega)$ that associates with the CD3 complex early during biosynthesis but does not travel with the receptor to the plasma membrane (63). CD3- $\omega$ could be detected in human peripheral $\mathrm{T}$ lymphocytes, human $\mathrm{T}$ leukemia cell lines $(58,63)$ and murine $\mathrm{T}-\mathrm{T}$ hybridomas (B. Alarcon, unpublished). More recently, we have provided evidence that CD3- $\omega$ also associates with single TCR- $\alpha$ and $-\beta$ chains. Associations with CD3- $\omega$ occur before the N-linked glycans of the receptor complex have been processed and probably take place in the endoplasmic reticulum (58). Based on partial N-terminal sequence data and on the lack of cross-reactivity with any of the anti-TCR or -CD3 reagents, CD3- $\omega$ appears to be distinct from the other members of the complex (63 and B. Alarcon, unpublished).

What role does CD3- $\omega$ play in assembly and transport? The export of individual chains of the CD3/TCR complex and the fully assembled receptor itself from the ER is slow. Given that approximately half of the membrane of the ER vesicularizes and moves to the Golgi every $10 \mathrm{~min}$ (64), it seems probable that the polypeptides of the receptor are actively retained within the ER. CD3- $\omega$ may retain partially assembled complexes at the site of assembly until the process is completed. In a comparable system, Ig heavy chains assemble with a protein termed BiP. Assembly takes place in the ER, displacing BiP from the Ig heavy chain (64).

Unfortunately, a retention model cannot be completely reconciled with 
the observed rapid degradation of individual chains and incomplete receptors. Such observations require that the chains in question leave the ER. It is likely that retention and targeting for degradation are coupled. The CD3- $\omega$ chain may be involved in the transport of receptor-"subcomplexes" from the ER to lysosomes. This notion is supported by the observation that the $\mathrm{CD} 3-\gamma,-\delta$, and $-\varepsilon$ complexes are stabilized by treatment with monensin (63). Pulse-chase biosynthesis experiments show that CD3- $\omega$ dissociates from the TCR/CD3 complex early during biosynthesis. The mechanisms that control this dissociation remain unknown. It could be that CD3- $\omega$ is displaced during the final stages of assembly. Alternatively, CD3- $\omega$ could act as a catalyst of assembly, which, for instance, could be necessary to provide for a microenvironment in the membrane which would be destabilized by the charged residues in the transmembrane segments. On the other hand, no CD3- $\omega$ has been detected in COS cell transfectants. It is therefore possible that CD3- $\omega$ may not be necessary for the CD $3-\gamma, \delta, \varepsilon$ core assembly.

In conclusion, the role of this newly detected CD3- $\omega$ protein could be in: (a) retention of unassembled subcomplexes in the endoplasmic reticulum; $(b)$ guiding unassembled chains and subcomplexes towards the degradative pathway: (c) facilitating assembly.

\section{SIGNAL TRANSDUCTION TRIGGERED VIA THE TCR/CD3 COMPLEX}

Numerous studies have made it clear that occupancy of the TCR/CD3 complex results in a series of early metabolic events that lead to $\mathrm{T}$ cell activation (65). While the cytoplasmic domains of the TCR polypeptide chains are extremely short, CD3 polypeptide chains contain substantially longer intracellular domains (Figure 3 ) and are therefore likely to mediate signal transduction upon antigen recognition by the TCR heterodimer. None of the CD3 genes cloned so far contains kinase domains or GTP binding sites, although these have been found in growth factor receptors. Signal transduction through the TCR/CD3 protein ensemble will therefore probably involve currently unidentified membrane or cytoplasmic proteins.

Early changes observed after triggering of the TCR/CD3 complex with either antigen of MAb are: a rise in intracellular $\mathrm{Ca}^{2+}$, a stimulated $\mathrm{K}^{+}$ efflux (66), increase of the turnover of phosphoinositides, activation of protein kinase $\mathrm{C}$, and a rise of the intracellular $\mathrm{pH}$ by activation of a $\mathrm{Na}^{+} / \mathrm{H}^{+}$antiporter. In addition, poorly defined secondary signals provided by accessory cells like macrophages act synergistically in the induc- 
tion of $\mathrm{T}$ cell proliferation. This discussion is confined to several early events in $\mathrm{T}$ cell activation via the TCR/CD3 pathway and the role of phosphorylation of the TCR/CD3 complex.

\section{The Role of $\mathrm{Ca}^{2+}$ and Phosphatidyl Inositol in $T$ Cell Activation}

Historically, many investigations have shown that $\mathrm{Ca}^{2+}$ ions play a crucial role in $\mathrm{T}$ cell activation. The induction of $\mathrm{T}$ cell proliferation and cytotoxic activity is blocked reversibly by $\mathrm{Ca}^{2+}$ chelators. Several groups have shown that triggering of the TCR/CD3 complex of resting T cells, $\mathrm{T}$ cell clones, and $\mathrm{T}$ leukemic cell lines by MAbs, mitogenic lectins, or appropriately presented antigen results in a rise in intracellular free $\mathrm{Ca}^{2+}\left[\left(\mathrm{Ca}^{2+}\right)_{\mathrm{i}}\right]$. In the leukemic cell line Jurkat, an initial rise in $\left(\mathrm{Ca}^{2+}\right)_{i}$ is mediated by the transient release of $\mathrm{Ca}^{2+}$ from intracellular stores; a sustained elevation of $\left(\mathrm{Ca}^{2+}\right)_{\mathrm{i}}$ occurs only if extracellular $\mathrm{Ca}^{2+}$ is available. Similarly, in resting human or murine $\mathrm{T}$ cell lines (64a) and in $\mathrm{T}$ cell clones, the major component of the rise in $\left(\mathrm{Ca}^{2+}\right)_{\mathrm{i}}$ is caused by an influx of $\mathrm{Ca}^{2+}$ from the extracellular milieu (see 65 for review).

Recently, Kuno et al identified mitogen-dependent $\mathrm{Ca}^{2+}$ channels in human $T$ cells using a patch clamp technique (69). The authors recorded opening of putative $\mathrm{Ca}^{2+}$ channels in cloned human $\mathrm{T}$ helper cells after addition of PHA or anti-CD3 MAb outside the patch pipette. It was argued that the gigaohm seal of the patch pipette prevented the entry of the inducing reagent into the patch area where the changes were recorded, pointing to the requirement for an intermediary metabolic event. The nature of one such metabolic intermediate is discussed below.

In a rapidly growing number of receptor activation models, $\mathrm{Ca}^{2+}$ mobilization results from ligand-induced signaling through the phosphatidyl inositol (PI) pathway. This bifurcated second messenger mechanism involves the hydrolysis of PI 4,5 bisphosphate into the biologically active substances inositol 1,4,5 trisphosphate ( $\mathrm{IP}_{3}$ ) and diacylglycerol (DAG) upon receptor activation. $\mathrm{IP}_{3}$ subsequently indues a rise in $\left(\mathrm{Ca}^{2+}\right)_{i}$; DAG activates a key enzyme in cellular activation, protein kinase $C$ (67). Most of the biochemical parameters associated with ligand induced PI hydrolysis have indeed been observed in T cells stimulated through the TCR/CD3 complex. The formation of $\mathrm{IP}_{3}$ has been measured upon activation of the TCR/CD3 complex by MAb (65) and by antigen (68). Moreover, $\mathrm{IP}_{3}$ has been shown to mediate the release of $\mathrm{Ca}^{2+}$ from saponin-permeabilized Jurkat cells (65), indicating that $\mathrm{IP}_{3}$ indeed mobilizes $\mathrm{Ca}^{2+}$ in $\mathrm{T}$ cells. This notion is corroborated by a recent study demonstrating the presence of $\mathrm{IP}_{3}$-activated $\mathrm{Ca}^{2+}$ channels in the $\mathrm{T}$ cell membrane (69). The direct involvement of protein kinase $\mathrm{C}$ in $\mathrm{T}$ cell activation is evidenced by its 
translocation from cytosol to the membrane upon perturbation of the TCR/CD3 complex (70).

Given the observations described, it could be hypothesized that coupling of phospholipase $\mathrm{C}$ to the TCR/CD3 complex is mediated via $\mathrm{G}$ proteins. Some indirect evidence for the involvement of GTP-binding proteins in T cell activation has recently been obtained (71). However, definitive proof for such a coupling will require more detailed biochemical studies.

\section{CD3 Phosphorylation Accompanies T Cell Activation}

Human T lymphocytes exposed to phorbol esters, ionomycin, the mitogen $\mathrm{PHA}$, or antigen and cultured in the presence of ${ }^{32} \mathrm{P}$ phosphate contain a phosphorylated CD3- $\gamma$ chain. Some experiments involving induction of a phosphorylated human CD3- $\delta$ or CD3- $\varepsilon$ have been reported $(72,73)$.

Further analysis of the CD3- $\gamma$ chain showed that a single site (serine 126) was phosphorylated when T lymphocytes were stimulated by PHA or PMA. In contrast, two sites (serines 123 and 126) were phosphorylated in response to the $\mathrm{Ca}^{2+}$ ionophore ionomycin (72). Thus, these phosphorylation events may reflect the regulation of phosphorylation by two independent pathways.

Many cell surface structures have the ability to recycle. In particular receptor molecules that deliver ligands to the cell, e.g. transferrin receptor or LDL-receptor, are endocytosed and reappear on the cell surface rather rapidly. It had been observed that antibodies directed at human TCR or CD3 are endowed with the ability to induce TCR/CD3 internalization (74). When it was found that phorbolesters similarly could induce internalization, a careful study of the relationship between phosphorylation of the TCR/CD3 complex and endocytosis was conducted by Krangel (75). Phosphorylated forms of the CD3- $\gamma$ protein were shown to be constitutively endocytosed, while nonphosphorylated forms of the molecule were excluded from that pathway. Similar results were obtained in mouse $\mathrm{T}$ lymphocytes $(37,38)$. It thus appears that the phosphorylation of CD3$\gamma$ mediates a down regulation of the TCR/CD3 complex. How this down regulation is coordinated with antigen-specific $\mathrm{T}$ cell activation needs to be resolved.

In a series of studies, Samelson et al have provided strong evidence for antigen-induction of tyrosine phosphorylation of a polypeptide (CD3-p21) associated with the antigen receptor on murine $T$ cells $(40,41,76)$. The isolated TCR/CD3 complex does not appear to have tyrosine kinase activity and must therefore be coupled to an as-yet-unknown kinase. In contrast to the antigen-induced tyrosine phosphorylation in helper $\mathrm{T}$ cell lines, $\mathrm{T}$ cells of some immunodeficiency mice (gld and $\mathrm{lpr}$ ) contain a constitutively tyrosine phosphorylated CD3-p21 (41). Since the lpr and 
gld $\mathrm{T}$ cells are inert in terms of their responses to antigen or lectins, it is possible that the CD3-p21 phosphorylation causes desensitization of the TCR/CD3 complex resulting in a decreased efficacy of signal transduction. The disulfide linkage of CD3-p21 and CD3- $\zeta$ may be a prerequisite for phosphorylation of CD3-p21. Thus, both CD3-p21 and CD3- $\zeta$ may turn out to play a pivotal role in the TCR/CD3 transduction mechanism.

\section{Interactions Between the TCR/CD3- and Antigen-Independent Activation Pathways}

All of the biochemical changes accompanying TCR/CD3 triggering occur in purified $\mathrm{T}$ cell populations or in single $\mathrm{T}$ lymphocytes. However, the proliferative response to anti-TCR/CD3 reagents and the production of the lymphokines Il-2 and $\gamma$-interferon require the presence of macrophages capable of interacting with the activating MAb through their surface Ig receptors.

In an attempt to circumvent the macrophage-dependency of $\mathrm{T}$ cell proliferation, a number of manipulations have been defined that, in concert with anti TCR/CD3 monoclonal antibodies, result in T cell proliferation and lymphokine production. Some groups have observed that the monokine IL-1 can function as an additional signal for T cell activation, although this could not be confirmed by others. Furthermore, the phorbol ester PMA, an irreversible activator of protein kinase $\mathrm{C}$, at low concentrations synergizes strongly with anti-TCR/CD3 Mabs in the induction of T cell proliferation (65). However, despite the studies described above and numerous others on this subject, the nature of the elusive secondary signal is not understood.

Several antigens like CD2, CD28, CD4 and CD8 and Thy-1 have been identified that, upon triggering with Mabs synergize with anti-TCR/CD3 monoclonal antibodies to induce functional responses in $\mathrm{T}$ cells. Antibodies to the adhesion molecule CD2 specifically block $\mathrm{T}$ cell functions. Different CD2 epitopes have been defined that either block (CD2-1) or activate (CD2-2 plus 3 ) $\mathrm{T}$ cell proliferation or killer function $(92,93)$. As does the CD3 pathway, activation of T cells via CD2 utilizes the hydrolysis of PI phosphates for its signal transduction (94). The CD2 pathway proceeds normally in CD3-negative NK cells (95). However, anti-CD3 Mabs block the CD2 pathway in thymocytes (96). Also, modulation of the TCR/CD3 complex from cloned $\mathrm{T}$ cells abolishes their response to anti$\mathrm{CD} 2$ Mabs. It has been hypothesized that the interaction between the CD2 and the TCR/CD3 pathways accounts for the elimination of autoreactive cells in the thymus. In this model it is proposed that thymocytes are 
activated to grow via the $\mathrm{CD} 2$ pathway. Whenever the TCR/CD3 complex is triggered simultaneously by autoantigens, the growth of such thymocytes is blocked and they eventually die (97).

Similarly a large body of data supports the notion that CD4 and CD8 act in concert with the TCR to optimize responses to TCR-antigen interactions. Both transfection studies (98-101) and experiments with monoclonal antibodies (15a) support the idea that the signal transduction pathways of TCR/CD3 and CD4 synergize. Suggestions that TCRs can form transient complexes on the cell surface with CD4 have not yet been supported by biochemical studies.

CD28, initially identified by the Moab 9.3 , is expressed on a subset of mature T cells (102). The 9.3 antibody is mitogenic for resting T cells in the presence of macrophages or the phorbol ester PMA. Like the TCR/CD3 complex, CD28 possibly signals through the PI pathway, since crosslinking of this antigen on the $\mathrm{T}$ cell surface mobilizes $\mathrm{Ca}^{2+}(103)$. Moretta et al recently isolated variants of Jurkat cells that lacked CD 3 but expressed CD28. These variant cells failed to produce IL-2 after triggering with 9.3 (104), indicating that activation via CD28 requires the presence of the TCR/CD3 complex.

The isolated murine Thy-1.2 gene has bcen transfected into Jurkat cells (a human T leukemic cell line) and into murine B cell lines (105). Transfectant cells that expressed the Thy-1.2 antigen demonstrated a rapid rise of intracellular $\mathrm{Ca}^{2+}$ upon addition of anti-Thy-1 antibodies. This could also be done in the $\mathrm{B}$ lymphoma cell lines. The induction of a rise in intracellular $\mathrm{Ca}^{2+}$ was therefore thought to be independent of the presence of the TCR/CD3 complex on the surface of Thy-1 expressing cells.

Mutant Jurkat cell lines that lack surface expression of TCR/CD3 and their revertants were recently used for transfection of the Thy-1.2 gene (106). Normal TCR/CD3 ${ }^{+}$Jurkat cells responded to anti-Thy- 1 antibodies with a rise in $\left(\mathrm{Ca}^{2+}\right)_{i}$ and, in the presence of phorbolesters, with IL-2 secretion. TCR $/ \mathrm{CD}^{-}{ }^{-}$variants responded to anti-Thy antibodies with the rise in $\mathrm{Ca}^{++}$but did not secrete IL-2 in the presence of phorbolester. The anti-Thy 1-induced IL-2 secretion was restored in TCR/CD3 + "revertants" transfected with the TCR $\alpha$ or $\beta$ cDNA (106). Similar results were obtained by Schmitt-Verhulst and colleagues (107) who selected variants of a murine CTL clone that had lost expression of the TCR $\alpha$ chain mRNA and which expressed normal amounts of Thy- 1 on its surface. Antibodies to Thy- 1 did not cause activation as measured by interferon $\gamma$ secretion. These data demonstrate unequivocally that Thy- 1 mediated T-cell activation, as measured by IL-2 or interferon- $\gamma$ production, requires coexpression of the $\mathrm{TCR} / \mathrm{CD} 3$ complex. 


\section{THE STRUCTURE AND REGULATION OF THE CD3 GENES}

\section{Expression of the TCR/CD3 Genes During Thymic Maturation}

The $\mathrm{T}$ lineage pathway of differentiation represents one of a few such pathways that are initiated during fetal development and persist in the adult animal. Bone marrow-derived prothymocytes go through several stages of differentiation in the thymus to give rise to immunocompetent $\mathrm{T}$ lymphocytes. The mechanisms governing this process are incompletely understood, but center around the generation of diversity of TCR-specificity followed by the selection of a limited number of mature $T$ cells to be added to the immune system (see 1 and 77 for review).

During fetal development in the mouse the first detectable population of thymocytes is a CD4- $4^{-} \mathrm{CD}^{-}$("double-negative") subset at day 14 of gestation (78). At days 16 and 17, double-positive and mature singlepositive $\mathrm{T}$ cells begin to be detectable and increase in proportion. A distribution of the different thymocyte-subsets similar to that found in the adult thymus is reached by day 19 of fetal life. To demonstrate putative precursor/progeny relationships, experiments of adoptive transfer, organ culture, and culture of isolated cells have been performed. The doublenegative subset has been demonstrated to generate all the other subsets $(79,80)$. On the contrary, it has not been possible to generate singlepositive mature thymocytes from the double-positive subset. Whether this subset represents an intermediary stage or an end point in $\mathrm{T}$ cell differentiation (see Figure 6) is still controversial.

The $T$ cell receptor genes are rearranged and expressed sequentially during maturation in both thymic ontogeny and adult thymus (see 1 and 77 for review). The first gene to be rearranged is TCR- $\gamma$ at day 14 of murine fetal development (81), followed by TCR- $\beta$ gene rearrangement. TCR- $\alpha$ gene rearrangements are first detected at day 16. Levels of detectable transcripts of the TCR genes parallel the occurrence of their respective rearrangements.

Appearance of the TCR/CD3 complex on the surface of thymocytes requires transcription of the genes of all of its members. In two exhaustive studies of normal thymocytes as well as of a series of human leukemias it was reported that all cells analyzed expressed CD3-transcripts and CD3proteins $(82-84,91)$. Thymocytes or leukemic cells that contain TCRtranscripts do express the TCR/CD3-complex on the cell surface, whereas the ones lacking at least TCR- $\alpha$ mRNA accumulate CD3- $\gamma, \mathrm{T} 3-\delta$, and T3$\varepsilon$ chains intracellularly, in the perinuclear envelope. In addition, thymocytes of the double-negative subset lack TCR- $\beta$ transcripts yet have 


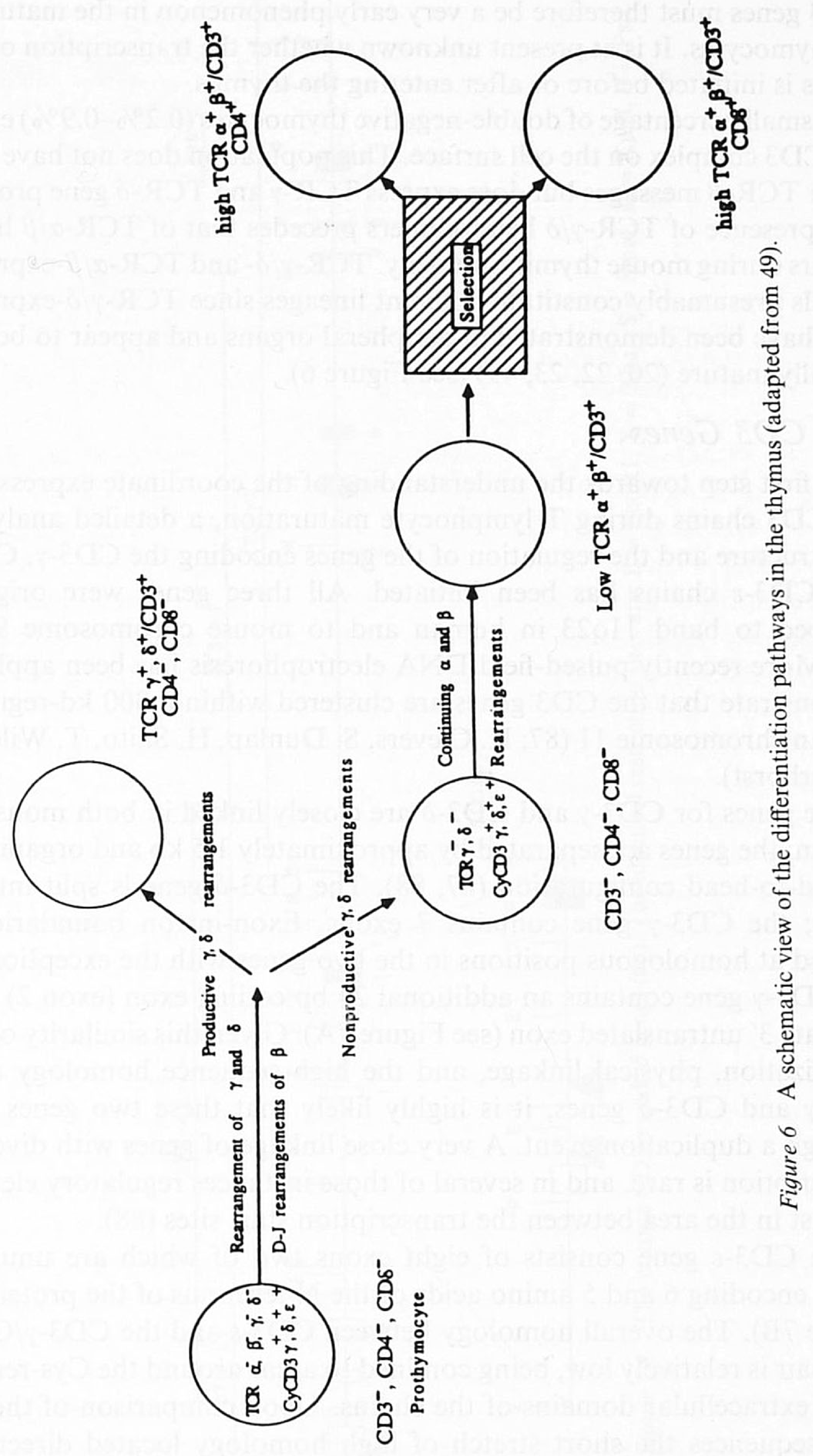


intracellular CD3 proteins (83). The transcription and translation of the CD3 genes must therefore be a very early phenomenon in the maturation of thymocytes. It is at present unknown whether the transcription of CD3 genes is initiated before or after entering the thymus.

A small percentage of double-negative thymocytes $(0.2 \%-0.9 \%)$ express the CD3 complex on the cell surface. This population does not have TCR$\alpha$ nor TCR- $\beta$ messages but does express TCR $-\gamma$ and TCR $-\delta$ gene products. The presence of TCR $-\gamma / \delta$ heterodimers precedes that of TCR $-\alpha / \beta$ heterodimers during mouse thymic ontogeny. TCR- $\gamma / \delta$ - and TCR- $\alpha / \beta$-expressing $\mathrm{T}$ cells presumably constitute different lineages since TCR- $\gamma / \delta$-expressing cells have been demonstrated in peripheral organs and appear to be functionally mature $(20,22,23,49)$ (see Figure 6).

\section{The CD3 Genes}

As a first step towards the understanding of the coordinate expression of the CD3 chains during $\mathrm{T}$ lymphocyte maturation, a detailed analysis of the structure and the regulation of the genes encoding the CD3- $\gamma, \mathrm{CD} 3-\delta$, and CD3- $\varepsilon$ chains has been initiated. All three genes were originally mapped to band 11q23 in human and to mouse chromosome 9 (8587). More recently pulsed-field DNA electrophoresis has been applied to demonstrate that the CD3 genes are clustered within a $300 \mathrm{kd}$-region on human chromosome 11 (87; H. Clevers, S. Dunlap, H. Saito, T. Wileman, C. Terhorst).

The genes for CD3- $\gamma$ and CD3- $\delta$ are closely linked in both mouse and human; the genes are separated by approximately $1.5 \mathrm{~kb}$ and organized in a head-to-head configuration $(87,88)$. The CD3- $\delta$ gene is split into five exons; the CD3- $\gamma$ gene contains 7 exons. Exon-intron boundaries are located at homologous positions in the two genes with the exception that the CD3- $\gamma$ gene contains an additional 24 bp coding exon (exon 2) and a separate $3^{\prime}$ untranslated exon (see Figure 7A). Given this similarity of gene organization, physical linkage, and the high sequence homology of the CD $3-\gamma$ and CD3- $\delta$ genes, it is highly likely that these two genes arose through a duplication event. A very close linkage of genes with divergent transcription is rare, and in several of those instances regulatory elements do exist in the area between the transcription start sites (88).

The CD3- $\varepsilon$ gene consists of eight exons two of which are unusually small, encoding 6 and 5 amino acids of the $\mathrm{N}$ terminus of the protein (see Figure 7B). The overall homology between CD3- $\varepsilon$ and the CD3- $\gamma / \mathrm{CD} 3-\delta$ gene pair is relatively low, being confined to areas around the Cys-residues in the extracellular domains of the chains. Upon comparison of the genomic sequences the short stretch of high homology located directly $\mathrm{N}$ terminal of the transmembrane segment $(53,55)$ was found to coincide 

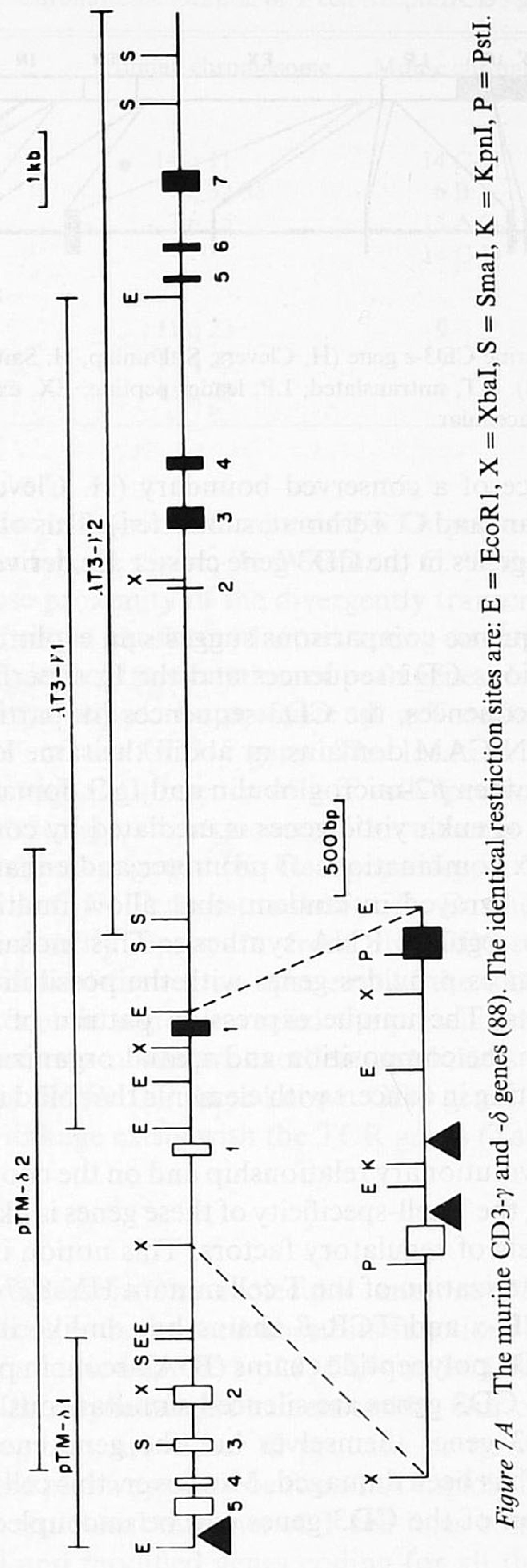


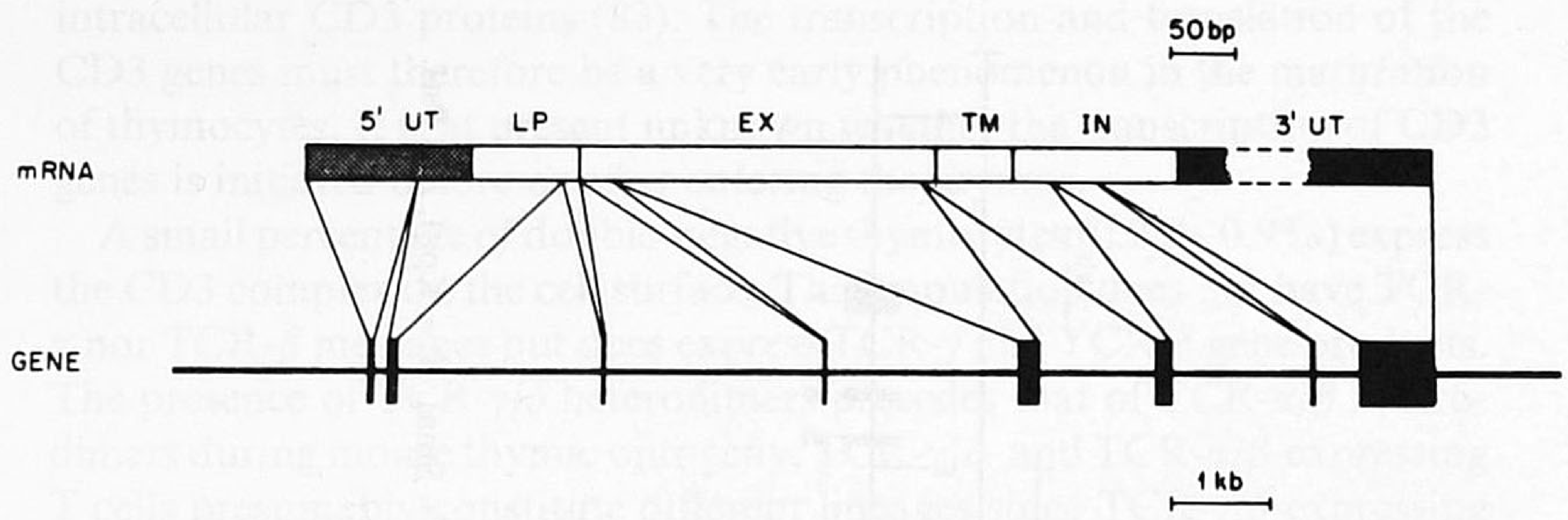

Figure $7 B$ The murine CD3- $\varepsilon$ gene $(H$. Clevers, S. Dunlap, H. Saito, T. Wileman, and C. Terhorst, submitted). UT, untranslated; LP, leader peptide; EX, extracellular; TM, transmembrane; IN, intracellular.

with the presence of a conserved boundary $(\mathrm{H}$. Clevers, S. Dunlap, H. Saito, T. Wileman, and C. Terhorst, submitted). This observation strongly suggests that all genes in the $\mathrm{CD} 3$ gene cluster are derived from a common ancestral gene.

A series of sequence comparisons suggests an evolutionary relationship between the various CD3 sequences and the Ig superfamily. Among the Ig-superfamily sequences, the CD3 sequences (in particular CD3- $\varepsilon$ ) may fit best with the N-CAM domains, at about the same level of significance as those seen between $\beta 2$-microglobulin and $\operatorname{IgG}$ domains $(54,108)$.

Transcription of eukaryotic genes is mediated by control regions composed of complex combinations of promoter and enhancer elements (cisacting elements), arrayed in tandem, that allow multiple distinct transacting factors to regulate RNA synthesis. This mosaic arrangement of regulatory sequences provides genes with the possibility of using sets of common elements. The unique expression pattern of any given gene is obtained through the composition and spatial organization of such com$n_{1}$ on elements, acting in concert with elements that bind inducible or tissuespecific factors.

Based on the evolutionary relationship and on the coordinate expression of the CD3 genes, the T cell-specificity of these genes is likely to be governed by overlapping sets of regulatory factors. This notion is corroborated by the recent characterization of the T cell mutant HY-827-P19. This cell line expresses the TCR- $\alpha$ and TCR- $\beta$ chains but, unlike its parent cell line, lacks all of the CD3 polypeptide chains (B. Alarcon, in preparation). Since in this mutant all CD3 genes are silenced simultaneously, it is most likely that not the CD3 genes themselves but the gene encoding a common regulatory factor has been damaged. Moreover, this cell line demonstrates that the expression of the CD3 genes can be uncoupled from TCR gene expression. 
Table 2 Chromosome location of $\mathrm{T}$ cell receptor/CD3 genes

\begin{tabular}{lcc}
\hline \hline & Human chromosome & Mouse chromosome \\
\hline TCR & & \\
$\alpha$ & $14 \mathrm{q} 11$ & $14 \mathrm{C}-\mathrm{D}$ \\
$\beta$ & $7 \mathrm{q} 32-35$ & $6 \mathrm{~B}$ \\
$\gamma$ & $7 \mathrm{p} 15$ & $13 \mathrm{~A} 2-3$ \\
$\delta$ & - & $14 \mathrm{C}-\mathrm{D}$ \\
$\mathrm{CD} 3$ & & \\
$\gamma$ & $11 \mathrm{q} 23$ & 9 \\
$\delta$ & $11 \mathrm{q} 23$ & 9 \\
$\varepsilon$ & $11 \mathrm{q} 23$ & 9 \\
\hline
\end{tabular}

All CD3 genes are transcribed from non-TATA promoters (56a, 87-89, H. Clevers, S. Dunlap, H. Saito, T. Wileman, C. Terhorst, submitted). Because of the close proximity of the divergently transcribing CD3- $\gamma$ and CD3- $\delta$ promoters, single regulatory factors acting on the intervening gene segment potentially affect transcription of both genes. In vitro gene regulation analysis has revealed the presence of a $\mathrm{T}$ cell-specific enhancer element directly $3^{\prime}$ of the CD3- $\delta$ gene. The location of this enhancer element coincides with the presence of a $\mathrm{T}$ cell-specific DNase I hypersensitive site. Interestingly, the sequence of this element is repeated in the CD3 $-\gamma /$ CD3 $-\delta$ intergenic segment (K. Georgopoulos, P. Van den Elsen, E. Bier, A. Maxam, and C. Terhorst, submitted). Furthermore, a similar motif is present directly upstream from the CD3- $\varepsilon$ gene promoter. Sequence comparison of the region upstream of the CD3- $\varepsilon$ gene with the CD3- $\gamma / \mathrm{CD} 3-\delta$ intergenic region revealed the presence of another homologous motif. These two motifs are excellent candidates for $\mathrm{T}$ cell-specific cis-acting elements. While the three known CD3 genes are closely linked to each other, no linkage exists with the TCR genes (Table 2).

\section{CONCLUSION}

Despite rapid progress in the molecular anatomy of the TCR/CD3 complex, much needs to be learned about its function. Several new polypeptide chains (in addition to CD3-p21, CD4 and CD8) will probably be found coupled to this dynamic protein ensemble. Our current knowledge would predict that they are either G-proteins or tyrosine kinases. Yet, completely different pathways may be found. A rapidly increasing number of functional and structural mutants of $\mathrm{T}$ cell lines combined with transfection of normal and modified genes coding for all the members of the 
ensemble will facilitate these new discoveries. However, even if the molecular interactions of the TCR/CD3 complex are worked out, the synergism with other $\mathrm{T}$ cell surface structures in the induction of $\mathrm{T}$ lymphocyte proliferation needs to be understood.

Future studies of assembly of the TCR/CD3 complex will answer major questions about retention in the endoplasmic reticulum, the existence of a hitherto unknown intracellular transport pathway, and the regulation of the level of cell surface expression during thymic differentiation. Future studies of the coordinate regulation of transcription of the TCR and of the CD3 genes will be of interest as a model of $\mathrm{T}$ cell-specific gene expression.

Thus, principles of signal transduction by the TCR/CD3 complex, of its assembly, and of the regulation of its genes will not only be of great interest to $T$ cell biologists but will have general implications in the fields of developmental and cell biology.

\section{ACKNOWLEDGMENTS}

The authors wish to thank Drs. C. Hall and J. Bergelson for critically reading the manuscript; Drs. L. Samelson, A. Weiss, J. Coligan, D. Pardoll, and A. Kruisbeek for sharing experimental data; and J. W. Lockhart for expert secretarial assistance. H. Clevers is supported by a fellowship from the Dutch Cancer Society (KWF), B. Alarcon is supported by a fellowship from E.M.B.O., T. Wileman is a fellow of the Puritan Bennett Foundation. These studies were supported by NIH grants AI-15066 and AI-17651, and ACS grant No. IM-289E.

\section{Literature Cited}

1. Allison, J. P., Lanier, L. L. 1987. The structure, function, and serology of the T cell antigen receptor complex. Ann. Rev. Immunol. 5: 503-40

2. Toyonaga, B., Mak, T. 1987. Genes of the $T$ cell antigen receptor in normal and malignant T cells. Ann. Rev. Immunol. 5: 585-620

3. Kronenberg, M., Siu, G., Hood, L. E., Shastri, N. 1986. The molecular genetics of the $\mathrm{T}$ cell antigen receptor and T cell antigen recognition. Ann. Rev. Immunol. 4: 529-41

4. Spits, H., Schooten, W. V., Keizer, H., Seventer, G. V., Van de Rijn, M., Terhorst, C., De Vries, J. E. 1986. Alloantigen recognition is preceded by a non-specific adhesion of cytotoxic $\mathrm{T}$ cells and target cells. Science 232: 403 5

5. Yague, J., White, J., Coleclough, C., Kappler, J., Palmer, E., Marrack, P. 1985. The T cell receptor: The $\alpha$ and $\beta$ chains define idiotype, and antigen and MHC specificity. Cell 42: 81

6. Dembic, Z., Haas, W., Weiss, S., McCubrey, J., Kiefer, H., von Boehmer, H., Steinmetz, M. 1986. Transfer of specificity by murine $\alpha$ and $\beta$ T cell receptor genes. Nature 320: 232

7. Brenner, M. B., McLean, J., Dialynas, D. P., Strominger, J. L., Smith, J. A., Owen, F. L., Seidman, J. G., Ip, S., Rosen, F., Krangel, M. S. 1986. Identification of a putative second $\mathrm{T}$ cell receptor. Nature 322: 145-49 
8. Borst, J., van de Griend, R. J., van Oostveen, J. W., Ang, S. L., Melief, C. J., Seidman, J. G., Bolhuis, R. L. H. 1987. The T cell receptor $\gamma /$ CD3 complex found on cloned functional lymphocytes. Nature 325: 683-87

9. Alarcon, B., Pettey, C., Boylston, A., Yssel, H., De Vries, J., Terhorst, C., Spits, H. 1987. A human NK like T cell clone uses the $\mathrm{T}$ cell receptor $\mathrm{y} / \mathrm{CD} 3$ complex in cytolysis. Proc. Natl. Acad. Sci. USA 84: 3861-65

10. Kappler, J. W., Roehm, N., Marrack, P. 1987. T cell tolerance by clonal elimination in the thymus. Cell 49: 273-80

11. Kappler, J. W., Wade, T., White, J., Kushnir, E., Blackman, M., Bill, J., Roehm, N., Marrack, P. 1987. A T cell receptor $\mathrm{V} \beta$ segment that imparts reactivity to a class II major histocompatibility complex product. Cell 49: 263-71

12. Matis, L. A., Sorger, S. B., McElligott, D. L., Fink, P. Z., Hedrick, S. M. 1987. The molecular basis of alloreactivity in antigen-specific, major histocompatibility complex-restricted $\mathrm{T}$ cell clones. Cell 51: 56-69

13. Springer, T. A., Dustin, M. L., Kishimoto, T. K., Marlin, S. 1987. The lymphocytes function associated LFA1, CD2, and LFA-3 molecules: cell adhesion receptors of the immune system. Ann. Rev. Immunol. 5: 223-52

14. Littman, D. 1987. The structure of the CD4 and CD8 genes. Ann. Rev. Immunol. 5: 561

15. Emmerich, F., Strittmatter, U., Eichmann, K. 1986. Synergism in the activation of human CD8 T cells by crosslinking the T cell receptor complex with the CD8 differentiation antigen. Proc. Natl. Acad. Sci. USA 83: 8298-8302

15a. Saizawa, K., Rojo, J., Janeway, C. A. Jr. 1987. Evidence for a physical association of CD4 and the CD3: $\alpha: \beta:$ T cell receptor. Nature 328: 260-63

16. Meuer, S. C., Cooper, D. A., Hodgdon, J. C., Hussey, R. E., Fitzgerald, K. A., Schlossman, S. F., Reinherz, E. L. 1983. Identification of the antigen/ MHC-receptor on human inducer T lymphocytes. Science 222: 1239

17. Haskins, K., Kubo, R., White, J., Pigeon, M., Kappler, J., Marrack, P. 1983. The major histocompatibility complex-restricted antigen receptor on $\mathrm{T}$ cells. I. Isolation with a monoclonal antibody. J. Exp. Med. 157: 1149-69

18. Hedrick, S. M., Cohen, D. I., Nielson, E. A., Davis, M. 1984. Isolation of cDNA clones encoding $T$ cell-specific membrane-associated proteins. Nature
308: 149

19. Yanagi, Y., Yoshikai, Y., Leggett, K., Clark, S. P., Aleksander, I., Mak, T. W. 1984. A human T cell-specific cDNA clone encodes a protein having extensive homology to immunoglobulin chains. Nature 308: 145

20. Lanier, L., Weiss, A. 1986. Presence of $\mathrm{Ti}$ (WT31) negative lymphocytes in normal blood and thymus. Nature 324: 268-70

21. Krangel, M. S., Bierer, B. E., Devlin, P., Clabby, M., Strominger, J. L., McLean, J., Brenner, M. B. 1987. T3 glycoprotein is functional although structurally distinct on human $\mathrm{T}$ cell receptor $\gamma / \mathrm{T}$ lymphocytes. Proc. Natl. Acad. Sci. USA 84: 3817-21

22. Lew, A. M., Pardoll, D. M., Maloy, W. L., Fowlkes, B. J., Kruisbeek, A., Cheng, S. F., Germain, R. N., Bluestone, J. A., Schwartz, R. K., Coligan, J. E. 1986. Characterization of T cell receptor gamma chain expression in a subset of murine thymocytes. Science 234: 1401-5

23. Pardoll, D. M., Fowlkes, B. J., Bluestone, J. A., Kruisbeek, A., Maloy, W. L., Coligan, J. E., Schwartz, R. 1987. Differential expression of two distinct $\mathrm{T}$ cell receptors during thymocyte development. Nature 326: 79-81

24. van Agthoven, A., Terhorst, C., Reinherz, C., Schlossman, S. F. 1981. Characterization of $\mathrm{T}$ cell surface glycoproteins T1 and T3 present on all human peripheral $\mathrm{T}$ lymphocytes and functionally mature thymocytes. Eur. J. Immunol. 11: 18-21

25. Borst, J., Prendiville, M. A., Terhorst, C. 1982. Complexity of the human T lymphocyte-specific cell surface antigen T3. J. Immunol. 128: 1560

26. Borst, J., Alexander, S., Elder, J., Terhorst, C. 1983. The T3 complex on human $\mathrm{T}$ lymphocytes involves four structurally distinct glycoproteins. $J$. Biol. Chem. 259: 5135

27. Kanellopoulos, J. M., Wigglesworth, N. M., Owen, M. J., Crumpton, M. J. 1983. Biosynthesis and molecular nature of the T3 antigen of human T lymphocytes. EMBO J. 2: 1807

28. Borst, J., Prendiville, M. A., Terhorst, C. 1983. The T3 complex on human thymus-derived lymphocytes contains two different subunits of $20 \mathrm{k} \mathrm{Da}$. Eur. J. Immunol. 13: 576

29. Borst, J., Colligan, J. E., Oettgen, H., Pessano, S., Malin, R., Terhorst, C. 1984. The $\delta$ and $\varepsilon$ chains of the human T3/T cell receptor complex are distinct polypeptides. Nature 312: 455 
30. Pessano, S., Oettgen, H., Bhan, A. K., Terhorst, C. 1985. The T3/T cell receptor complex: antigenic distinction between the 20-kd T3 (T3- $\delta$ and T3- $\varepsilon$ ) subunits. EMBO J. 4: 337

31. Meuer, S. C., Fitzgerald, K. A., Hussey, R. E., Hodgdon, J. C., Schlossman, S. F., Reinherz, E. 1983. Clonotypic structures involved in antigenspecific human $\mathrm{T}$ cell function: relationship to the T3 molecular complex. $J$. Exp. Med. 157: 705

32. Oettgen, H., Kappler, J., Tax, W. J. M., Terhorst, C. 1984. Characterization of the two heavy chains of the T3 complex on the surface of the human T lymphocytes. J. Biol. Chem. 259: 12039

33. Meuer, S. C., Acuto, O., Hussey, R. E., Hodgdon, J. C., Fitzgerald, K. A., Schlossman, S. F., Reinherz, E. L. 1983. Evidence for the T3-associated 90KD heterodimer as the T cell antigen receptor. Nature 303: 808

34. Zanders, E. D., Lamb, J. R., Feldman, M., Green, N., Beverly, P. C. L. 1983 Tolerance of $\mathrm{T}$ cell clones is associated with membrane antigen changes. Nature 303: 625

35. Ohashi, P., Mak, T., van den Elsen, P., Yanagi, Y., Yoshikai, Y., Calman, A., Terhorst, C., Stobo, J., Weiss, A. 1985. Reconstitution of an active surface T3/T cell antigen receptor by DNA transfer. Nature 316: 606

36. Saito, T., Weiss, A., Miller, J., Norcross, M. A., Germain, R. N. 1987. Specific antigen-Ia activation of transfected human T cells expressing murine Ti $\alpha \beta$-human T3 receptor complexes. Nature 325: 125

37. Samelson, L. E., Harford, J. B., Klausner, R. D. 1985. Identification of the components of the murine $\mathrm{T}$ cell antigen receptor complex. Cell 43: 223

38. Oettgen, H., Pettey, C., Maloy, W. Terhorst, C. 1986. A T3-like protein complex associated with an antigen receptor on murine T cells. Nature 320: 272-75

38a. Berkhout, B., Alarcon, B., Terhorst, C. 1987. Transfection of genes encoding the $\mathrm{T}$ cell receptor associated CD3 complex into COS cells results in assembly of the macromolecular structure. J. Biol. Chem. In press

39. Weissman, A. M., Samelson, L. E., Klausner, R. D. 1986. A new subunit of the human T-cell antigen receptor complex. Nature 324: 480-82

40. Samelson, L. E., Maitray, P. D., Weissman, A. M., Harford, J. B., Klausner, R. D. 1986. Antigen activation of murine $\mathrm{T}$ cells induces tyrosine phos- phorylation of a polypeptide associated with the $\mathrm{T}$ cell antigen receptor. Cell 46: 1083

41. Samelson, L. E., Davidson, W. F., Morse, H. C. III, Klausner, R. D. 1986. Abnormal tyrosine phosphorylation on T-cell receptor in lymphoproliferative disorders. Nature 324: 674

42. Novotny, J., Tonegawa, S., Saito, H., Kranz, D. M., Eisen, H. N. 1986. Secondary, tertiary, and quaternary structure of T cell specific immunoglobulinlike polypeptide chains. Proc. Natl. Acad. Sci. USA 83: 742-46

43. Saito, H., Kranz, D. M., Takagaki, Y., Hayday, A. C., Eisen, H. N., Tonegawa, S. 1984. Complete primary structure of a heterodimeric T-cell receptor deduced from cDNA sequences. $\mathrm{Na}$ ture 309: 757

44. Chien, Y. H., Becker, D. M., Lindsten, T., Okamura, M., Cohen, D. I., Davis, M. 1984. A third type of murine T-cell receptor gene. Nature 312: 31

45. Murre, C., Waldmann, R. A., Morton, C. C., Bongiovanni, D. F., Waldman, T. A., Shows, T. B., Seidman, J. G. 1985. Human $\gamma$-chain genes are rearranged in leukaemic $\mathrm{T}$ cells and map to the short arm of chromosome 7. Nature 316: 549

46. Brenner, M. B., McLean, J., Schejt, K., Riberdy, J., Ang, S. L., Seidman, J. G., Devlin, P., Krangel, M. S. 1987. Two forms of the T cell receptor $\gamma$ protein found on peripheral blood cytotoxic T lymphocytes. Nature 325: 689-94

47. Littman, D. R., Newton, M., Crommie, D., Ang, S.-L., Seidman, J. G., Gettner, S. N., Weiss, A. 1987. Characterization of an expressed CD3-associated $\mathrm{Ti} \gamma$-chain reveals $\mathrm{C} \gamma$ domain polymorphism. Nature 326 : 85-88

48. Moingeon, P., Jitsukawa, S., Faure, F., Troalen, F., Triebel, F., Graziani, M., Forestier, F., Bellet, D., Bohmon, C., Hercend, T. 1987. A $\gamma$-chain complex forms a functional receptor on cloned human lymphocytes with natural killer-like activity. Nature 325: 723-26

48a. Biron, C., van den Elsen, P., Tutt, M., Medveczky, P., Kumar, V., Terhorst, C. 1987. T cell receptor gene expression by Murine natural killer cells and $T$ cells stimulated In Vivo. J. Immunol. In press

49. Pardoll, D. M., Kruisbeek, A. M., Fowlkes, B. J., Coligan, J., Schwartz, R. H. 1987. The unfolding story of T cell receptor $\gamma$. FEBS J. 1: 103

50. Chien, Y., Iwashima, M., Kaplan, K., Elliott, A. J. F., Davis, M. 1987. A new 
$\mathrm{T}$-cell receptor gene located within the alpha locus and expressed early in differentiation. Nature 327: 677

51. van den Elsen, P., Shepley, B. A., Borst, J., Coligan, J., Markham, A. F., Orkin, S., Terhorst, C. 1984. Isolation of cDNA clones encoding the $20 \mathrm{~K}$ T3 glycoprotein of human T-cell receptor complex. Nature 312: 413-18

52. van den Elsen, P., Shepley, B. A., Cho, M., Terhorst, C. 1985. Isolation and characterization of a cDNA clone encoding the murine homologue of the human $20 \mathrm{~K}$ T3/T-cell receptor glycoprotein. Nature 314: 542-44

53. Gold, D., Puck, J., Pettey, C., Cho, M., Coligan, J., Woody, J., Terhorst, C. 1986. Isolation of cDNA clones encoding the $20 \mathrm{kD}$ non-glycosylated polypeptide chains (T3- $\varepsilon$ ) of the human T cell receptor/T3 complex. Nature 321: 431-34

54. Gold, D. P., Clevers, H., Alarcon, B., Dunlap, S., Novotny, J., Williams, A., Terhorst, C. 1987. Characterization and expression of the murine $\mathrm{T} 3-\varepsilon$ chain: relationship to the immunoglobulin supergene family. Proc. Natl. Acad. Sci. USA. In press

55. Krissansen, G. W., Owen, M. J., Verbi, W., Crumpton, M. J. 1986. Primary structure of the T3 $\gamma$ subunit of the T3/T cell antigen receptor complex deduced from cDNA sequences: evolution of the T $3 \gamma$ and $\delta$ subunits. EMBO J. 5: 17991808

56. Krissansen, G. W., Owen, M. J., Fink, P. J., Crumpton, M. J. 1987. Molecular cloning of the cDNA encoding the T3- $\gamma$ subunit of the mouse T31T cell antigen receptor complex. J. Immunol. 138: 3513-18

56a. Tunnacliffe, A., Sims, J. E., Rabbitts, T. K. 1986. T3- $\delta$ pre-mRNA is transcribed from a non-TATA promoter and is alternatively spliced in human cells. EMBO J. 5: 1245-52

56b. Aruffo, A., Seed, B. 1987. Molecular cloning of the CD2 antigen, the T-cell erythrocyte receptor, by a rapid immunoselection procedure. Proc. Natl. Acad. Sci. USA 84: 3365-69

57. Weiss, A., Stobo, J. D. 1984. Requirement for the coexpression of T3 and T cell antigen receptor on a malignant human T cell. J. Exp. Med. 160: 1284 99

58. Alarcon, B., Berkhout, B., Breitmeyer, J., Terhorst, C. 1987. Assembly of the human $\mathrm{T}$ cell receptor-CD3 complex takes place in the endoplasmic reticulum and involves intermediary complexes between the CD3- $(\gamma, \delta, \varepsilon)$ core and single $\mathrm{T}$ cell receptor $\alpha$ or $\beta$ chains. J. Biol. Chem. In press

59. McCleod, C., Mining, L., Gold, D., Terhorst, C., Wilkinson, M. 1986. Negative transregulation of T-cell antigen receptor/T3 complex mRNA expression in murine T-lymphoma somatic cell hybrids. Proc. Natl. Acad. Sci. USA 83: 6989-93

60. Regueiro, J. R., Arnaiz-Villera, Ortiz de Landazuri, M., Martin-Villa, J. M., Vicario, J. L., Pascual-Ruiz, V., Guerra-Garcia, F., Alcarni, J., Lopez-Botet, M., Manzanares, J. 1986. Familial defect of CD3 (T3) expression by T cells associated with rare gut epithelial cell autoantibodies. Lancet 1: 1.274-75

60a. Minami, Y., Weissman, A. M., Samelson, L. E., Klausner, R. D. 1987. Building a multichain receptor: Synthesis, degradation, and assembly of the T-cell antigen receptor. Proc. Natl. Acad. Sci. USA 84: 2688-92

61. Davis, G. L., Hunter, E. 1987. A charged amino acid substitution within the transmembrane anchor of the Roux Sarcoma virus envelope glycoprotein affects surface expression but not intracellular transport. J. Cell. Biol. 105: 1191-1203

62. Adams, G. A., Rose, J. K. 1985. Incorporation of a charged amino acid into the membrane spanning domain block cell surface but not membrane anchoring of a viral protein. Mol. Cell. Biol. 5: 1442-48

63. Pettey, C. L., Alarcon, B., Malin, R., Weinberg, K., Terhorst, C. 1987. T3p28 is a protein associated with the $\delta$ and $\varepsilon$ chains of the $T$ cell receptor-T3 antigen complex during biosynthesis. $J$. Biol. Chem. 262: 4854-59

64. Wieland, F. T., Gleason, M. L., Serafini, M., Rothman, J. 1987. The rate of bulk flow from the endoplasmic reticulum to the cell surface. Cell 50: 289300

64a. Oettgen, H. C., Terhorst, C., Cantley, L. C., Rosoff, P. M. 1985. Stimulation of the T3-T cell receptor complex induces a membrane-potentialsensitive calcium influx. Cell 40: 58390

65. Weiss, A., Imboden, J., Hardy, K., Manger, B., Terhorst, C., Stobo, J. 1986. The role of the T3/antigen receptor complex in T cell activation. Ann. Rev. Immunol. 4: 593-619

66. Matteson, D. R., Deutsh, C. 1984. K channels in $\mathrm{T}$ lymphocytes: a patch clamp study using monoclonal antibody adhesion. Nature 307: 468-71

67. Nishizuka, Y. 1984. The role of protein 
kinase $\mathrm{C}$ in cell surface signal transduction and tumor promotion. Nature 308: 693-98

68. Imboden, J., Weyand, C., Goronzy, J. 1987. Antigen recognition by a human $\mathrm{T}$ cell clone leads to increases in inositol trisphosphate. J. Immunol. 138: 132224

69. Kuno, M., Gardner, P. 1987. Ion channels activated by inositol 1,4,5-triphosphate in plasma membrane of human T-lymphocytes. Nature 326: 301-304

70. Nel, A. E., Bouic, P., Lattanze, G. R., Stevenson, H. C., Miller, P., Dirienzo, W., Stefanini, G. F., Galbraith, R. M. 1987. Reaction of T lymphocytes with anti-T3 induces translocation of $\mathrm{C}$ kinase activity to the membrane and specific substrate phosphorylation. $J$. Immunol.138: 3519-24

71. Imboden, J. B., Shoback, D. M., Pattison, G., Stobo, J. D. 1986. Cholera toxin inhibits the $T$ cell antigen receptor-mediated increases in inositol trisphosphate and cytoplasmic free calcium. Proc. Natl. Acad. Sci. USA 83: $5673-77$

72. Davies, A. A., Cantrell, D. A., Hexham, J. M., Parker, P. J., Rothbard, J., Crumpton, M. J. 1987. The human T3 $\gamma$ chain is phosphorylated at serine 126 in response to T lymphocyte activation. J. Biol. Chem. 262: 1

73. Cantrell, D., Davies, A. A., Londei, M., Feldman, M., Crumpton, M. J. 1987. Association of phosphorylation of the T3 antigen with immune activation of T lymphocytes. Nature 325: 540

74. Meuer, S., Acuto, O., Hercend, T., Schlossman, S., Reinherz, E. L. 1984. The human T cell receptor. Ann. Rev. Immunol. 2: 23-50

75. Krangel, M. S. 1987. Endocytosis and recycling of the T3-T cell receptor complex. The role of T3 phosphorylation. J. Exp. Med. 165: 1141-59

76. Minami, Y., Samelson, L. E., Klausner, R. D. 1987. Internalization and cycling of the T cell antigen receptor: role of protein kinase C. J. Biol. Chem. 262: 13342-47

77. Adkins, B., Mueller, C., Okada, C. Y., Richert, R. A., Weissman, I. L., Sprangmole, G. J. 1987. Early events in T cell maturation. Ann. Rev. Immunol. 5: 325-65

78. Mathieson, B., Sharrow, S., Rosemberg, Y., Hammerling, U. 1981. $\mathrm{Lyl}^{+} 23^{-}$cells appear in the thymus before Lyt $123^{+}$cells. Nature 289: 179
79. Kingston, R., Jenkinson, E. J., Owen, J. J. T. 1985. A single stem cell can recolonize an embryonic thymus, producing phenotypically distinct $\mathrm{T}$ cell populations. Nature 317: 811

80. Fowlkes, B. J., Edison, L., Mathieson, B. J., Chused, T. M. 1985. Early T lymphocytes: differentiation in vivo of adult intrathymic precursor cells. J. Exp. Med. 162: 802-22

81. Haars, R., Kronenberg, M., Gallatin, W. M., Weissman, I. L., Owen, F. L., Hood, L. 1986. Rearrangement and expression of $\mathrm{T}$ cell antigen receptor and $\gamma$ genes during thymic development. J. Exp. Med. 164: 1

82. Samelson, L. E., Londsten, T., Foulkes, B. J., van den Elsen, P., Terhorst, C., Druis, M. M., Germain, R. N., Schwartz, R. M. 1985. Expression of genes of the T-cell antigen receptor complex in precursor thymocytes. $\mathrm{Na}$ ture 315: 765-68

83. van Dongen, J. J. M., Quertermous, T., Bartram, C. R., Gold, D. P., WolversTettero, I. L. M., Comans-Bitter, W. M., Hooijkaas, H., Adriaansen, H. J., de Klein, A., Raghavachar, A., Ganser, A., Duby, A. D., Seidman, J. G., van den Elsen, P., Terhorst, C. 1987. T cell receptor-CD3 complex during early $\mathrm{T}$ cell differentiation: analysis of immature $\mathrm{T}$ cell acute lymphoblastic leukemias (T-ALL) at DNA, RNA, and cell membrane level. J. Immunol. 138: 1260-69

84. Furley, A. J., Mizutani, S., Weilbaecher, K., Dhaliwal, H. S., Ford, A. M., Chan, L. C., Molgaard, H. V., Toyonaga, B., Mak, T., van den Elsen, P., Gold, D., Terhorst, C., Greaves, M. F. 1986. Developmentally regulated rearrangement and expression of genes encoding the $\mathrm{T}$ cell receptor-T3 complex. Cell 46: 75-87

85. van den Elsen, P., Burns, G., Gerhard, D. S., Pravtcheva, D., Jones, C., Housman, D., Ruddle, F., Orkin, S., Terhorst, C. 1985. Assignment of the gene coding for the T3- $\delta$ subunit of the T3-T-cell receptor complex to the long arm of human chromosome 11 and to mouse chromosome 9. Proc. Natl. Acad. Sci. USA 82: 2920-24

86. Gold, D., van Dongen, J., Morton, C., Bruns, G., van den Elsen, P., Van Kessel, A., Terhorst, C. 1987. The gene encoding the $\varepsilon$-subunit of the T3/T-cell receptor complex maps to chromosome 11 in humans and to chromosome 9 in mice. Proc. Natl. Acad. Sci. USA 84: $1664-68$

87. Tunnacliffe, A., Buluwela, L., Rabbitts, 
T. H. 1987. Physical linkage of three CD3 genes on human chromosome 11. EMBO J. 6: 2953-57

88. Saito, H., Koyama, T., Georgopoulos, K., Clevers, H., Haser, W. G., LeBien, T., Tonegawa, S., Terhorst, C. 1987. Close linkage of the mouse and human CD $3-\gamma$ and $\delta$ genes suggests a control of their transcription by common regulatory elements. Proc. Natl. Acad. Sci. $U S A$. In press

89. van den Elsen, P., Georgeopoulos, K., Shepley, B. A., Orkin, S., Terhorst, C. 1986. Exon/intron organization of the genes coding of the $\delta$-chains of the human and murine $\mathrm{T}$ cell receptor/T3 complex. Proc. Natl. Acad. Sci. USA 83: $2944-48$

90. Kabat, E. A., Wu, T. T., Reid-Miller, M., Perry, H. M., Gottesman, K. S. 1987. Sequences of Proteins of Immunological Interest. Washington, DC: US Dep. Health Hum. Serv.

91. van Dongen, J. J. M., Krissansen, G. W., Wolvers-Tettero, I. L. M., Comans-Bitter, W., Adriaansen, H. J., Hooijkaas, van Wering, E. R., Terhorst, C. 1987. Cytoplasmic expression of the CD3 antigen as a diagnostic marker for immature $\mathrm{T}$ cell malignancies. Blood. In press

92. Meuer, S. C., Hussey, R. E., Fabbi, M., Fox, D., Acuto, O., Fitzgerald, K. A., Hodgdon, J. C., Protentis, J. P., Schlossman, S. F., Reinherz, E. L. 1984. An alternative pathway of T-cell activation: A functional role for the 50 kd T11 sheep erythrocyte receptor protein. Cell 36: 897-906

93. Siliciano, R. F., Pratt, J. C., Schmidt, R. E., Ritz, J., Reinherz, E. L. 1985. Activation of cytolytic T lymphocyte and natural killer cell function through the T11 sheep erythrocyte binding protein. Nature 428-30

94. Pantaleo, G., Olive, D., Poggi, A., Kozumbo, W. J., Moretta, L., Moretta, A. 1987. Transmembrane signalling via the T11-dependent pathway of human $\mathrm{T}$ cell activation. Evidence for the involvement of 1,2-diacylglycerol and inositol phosphates. Eur. J. Immunol. 17: $55-60$

95. Fox, D. A., Hussey, R. E., Fitzgerald, K. A., Bensussan, A., Daley, J. F., Schlossman, S. F., Reinherz, E. L. 1985. Activation of human thymocytes via the $50 \mathrm{kd} \mathrm{T11}$ sheep erythrocyte binding protein induces the expression of interleukin 2 receptors on both $\mathrm{T}^{+}$ and $\mathrm{T}^{-}$populations. J. Immunol. 134: 330-35

96. Ramarli, D., Fox, D. A., Milanese, C.,
Reinherz, E. L. 1986. Selective inhibition of interleukin 2 gene function following thymocyte antigen/major histocompatibility complex receptor crosslinking: Possible thymic selection mechanism. Proc. Natl. Acad. Sci. USA 83: 7008-12

97. Alcover, A., Ramarli, D., Richardson, N. E., Chang, H. S., Reinherz, E. L. 1987. Functional and molecular aspects of human T-lymphocyte activation via $\mathrm{T} 3 / \mathrm{Ti}$ and $\mathrm{T} 11$ pathways. Immunol. Rev. 95: 5-37

98. Dembic, Z., Haas, W., Zamoyaska, R., Parnes, J., von Boehmer, I. T., Steinmetz, M. 1987. Transfection of the CD8 gene enhances $\mathrm{T}$ cell recognition. Nature 326: 510-11

99. Gabert, J., Langlet, C., Zamoyska, R., Parnes, J. R., Schmitt-Verhulst, A. M., Malissen, B. 1987. Reconstitution of MHC-class I specificity by $\mathrm{T}$ cell receptor and Lyt-2 gene transfer. Cell 50: 545-54

100. Sleckman, B. P., Peterson, A., Jones, W. K., Foran, J. A., Greenstein, J. L., Seed, B., Burakoff, S. J. 1987. Expression and function of CD4 in a murine $\mathrm{T}$ cell hybridoma. Nature 328: 351-53

101. Gay, D., Maddon, P., Sekaly, R., Talle, M. A., Godfrey, M., Long, E., Goldstein, G., Chess, L., Axel, R., Kappler, J., Marrack, P. 1987. Functional interactions between human $\mathrm{T}$ cell protein CD4 and the major histocompatibility complex HLA-DR antigen. Nature 328: 626-29

102. Hansen, J. A., Martin, P. J., Nowinski, R. C. 1980. Monoclonal antibodies identifying a novel $\mathrm{T}$ cell antigen and Ig antigens of human lymphocytes. Immunogenetics 10: 225-29

103. Ledbetter, J. A., June, C. H., Grosmarie, L. S., Rabinovitch, P. S. 1987. Crosslinking of surface antigens causes mobilization of intracellular ionized calcium in T lymphocytes. Proc. Natl. Acad. Sci. USA 84: 1384-88

104. Moretta, A., Poggi, A., Olive, D., Bottino, C., Fortis, C., Pantaleo, G., Moretta, L. 1987. Selection and characterization of $\mathrm{T}$-cell variants lacking molecules involved in $\mathrm{T}$-cell activation (T3 T-cell receptor. T44, and T11): analysis of the functional relationship among different pathways of activation. Proc. Natl. Acad. Sci. USA 84: $1654-58$

105. Kroczek, R. A., Gunter, K. C., Germain, R. N., Shevach, E. M. 1986. Thy-1 functions as a signal transduction molecule in $\mathrm{T}$ lymphocytes and 
transfected B lymphocytes. Nature 322: $181-84$

106. Gunter, K. C., Germain, R. N., Kroczek, R. A., Saito, T., Yokoyama, W. M., Chan, C., Weiss, A., Shevach, E. 1987. Thy-1 mediated T cell activation requires coexpression of $\mathrm{CD} 3 / \mathrm{Ti}$ complex. Nature 326: 505-07

107. Schmitt-Verhulst, A. M., Guimezaes, A., Boyer, C., Poenie, M., Tsien, R., Buferne, M., Hua, C., Leserman, L. 1987. Pleiotropic loss of activation pathways in a $\mathrm{T}$ cell receptor alpha chain deletion variant of a cytolytic $\mathrm{T}$ cell clone. Nature 325: 628-31

108. Nguyen, C., Mattei, M.-G., Mattei, J.-F., Santoni, M.-J., Goridis, C., Jordan, B. R. 1986. Localization of the human NCAM gene to band q23 of chromosome 11: the third gene coding for a cell interaction molecule mapped to the distal portion of the long arm of chromosome 11. J. Cell Biol. 102: 71115 